\title{
Missing species among Mediterranean non-Siphonophoran Hydrozoa
}

\author{
Cinzia Gravili • Stanislao Bevilacqua • Antonio Terlizzi • \\ Ferdinando Boero
}

Received: 1 July 2014/Revised: 3 November 2014/ Accepted: 18 December 2014/

Published online: 20 January 2015

(C) The Author(s) 2015. This article is published with open access at Springerlink.com

\begin{abstract}
Hydrozoa of the Mediterranean Sea are well known and a recent monograph covers 457 species. Mediterranean non-Siphonophoran Hydrozoa comprises 398 species, an increasing number due to continuous updates, representing about $10 \%$ of the 3,702 currently valid species reported in a recent world assessment of hydrozoan diversity. Many new records are non indigenous species, previously described species that occurred elsewhere and whose arrival was presumably caused by human activities. However, many species reported in the past are not recorded in recent times. Realistic assessments of species pools require addition of new species, but also subtraction of species not found since a certain period. With the confidence of extinction index, cases of putative extinction can be raised. Out of the 398 known species, only 162 (41\%) have been reported in the last decade, while $53(13 \%)$ are not recorded in the literature since at least 41 years. According to the confidence of extinction index, $60 \%$ of the 53 missing species are extinct, and $11 \%$ are putatively extinct from the basin. From a biogeographical point of view, the missing species are: $34 \%$ endemic, $19 \%$ boreal, $15 \%$ Mediterranean-Atlantic, $11 \%$ Indo-Pacific, $11 \%$ circumtropical, $4 \%$ cosmopolitan, $2 \%$ tropical-Atlantic, $4 \%$ non-classifiable. Fluctuations in species composition into a certain area cause heavy variability in the expression of both structural and functional biodiversity. As consequence, the regional biodiversity should be analyzed through its temporal evolution, to detect changes and their possible causes. This approach has profound consequences on biodiversity assessments and also on the compilation of red lists.
\end{abstract}

Keywords Biodiversity $\cdot$ Hydrozoa $\cdot$ Extinction $\cdot$ Confidence of extinction index

Communicated by Dirk Sven Schmeller.

C. Gravili $(\bowtie) \cdot$ S. Bevilacqua $\cdot$ A. Terlizzi · F. Boero

Laboratory of Zoology and Marine Biology, Dipartimento di Scienze e Tecnologie Biologiche e Ambientali, Di.S.Te.B.A., Università del Salento, Via Prov.le Lecce-Monteroni, 73100 Lecce, Italy e-mail: cinzia.gravili@unisalento.it

F. Boero

CNR-ISMAR, Via de Marini, 6, 16149 Genoa, Italy 


\section{Introduction}

The question "How many species are there in the oceans?" provides the key to discover what we know and what we do not know about the life in the seas (Mora et al. 2011). Conservation biologists try to identify the areas in the world where effective conservation actions could protect as many species as possible. The knowledge of species, however, is incomplete since many species are still unknown (Costello et al. 2013a, b) or poorly known. Myers et al. (2000) claim that biodiversity hotspots, areas characterized by high numbers of endemic species as well as high rates of habitat loss, are prioritary, but a question remains: does the cumulative evaluation of biodiversity, in terms of species additions through time, really represent the expression of biodiversity at a given place?

Appeltans et al. (2012) compiled WoRMS, the World Register of Marine Species (about 226,000 eukaryotic marine species) and used it as a starting point for estimating how many more species may still be discovered. WoRMS published online information on marine species, but many nomenclatural and classification problems remain (Costello et al. 2013a, b). The introduction rate of synonyms is expected to decline through updated taxonomic revisions (Appeltans et al. 2012).

A further problem with the estimation of biodiversity is that local lists are usually updated by adding new entries, but locally (or even finally) extinct species are seldom, if ever, removed from the lists (Boero and Gravili 2013), a task that only taxonomists can undertake through the critical analysis of species lists and the identification of putatively extinct species.

The sea has been far less studied than the land, and our taxonomic knowledge of many groups remains fragmentary (Hilchey 2003). Attempts to inventory all known species led to cover about two-thirds of all marine species (Appeltans et al. 2012), and half of all species (Bisby et al. 2009). Species lists and their distribution are basic to biodiversity research (Costello et al. 2001). May (1994) and Hammond (1994) reviewed a variety of approaches to predict the number of species that may exist on Earth. Moreover, Costello and Wilson (2011) proposed to predict the number of known and unknown species in European seas using rates of description. Biodiversity research has a long history the Mediterranean Sea, one of the best-known seas globally (Coll et al. 2010; Gravili et al. 2013). In particular, the diversity of Mediterranean Hydrozoa is well known and has been recently updated (Bouillon et al. 2004, 2006; Schuchert 2005, 2006, 2008a, b, 2009, 2010; Galea 2007; De Vito et al. 2008; Gravili et al. 2007, 2008, 2010, 2013; Morri et al. 2009; Mastrototaro et al. 2010). The biodiversity of the Mediterranean Sea is high due to ecological, historical, and paleogeographic reasons (Sarà 1985; Bianchi and Morri 2000; Bianchi 2007). The western Mediterranean has strong Atlantic affinities, due to the continued penetration of Atlantic species (Harmelin and d'Hont 1993). Conversely, after the opening of the Suez Canal, the Eastern Mediterranean is receiving species from the Red Sea (Galil 1993). The number of Lessepsian species, now acclimated in the Mediterranean (Golani 1998), is so high that Por (1999) proposed a separate biogeographic province for the Levant Sea.

Many tropical NIS became recently established even in the northwestern Mediterranean waters (Coll et al. 2010; Lejeusne et al. 2010; Zenetos et al. 2012), forming stable populations (Bianchi and Morri 1993) as a response to a warming trend (Sparnocchia et al. 1994; Astraldi et al. 1995).

Ecological and biogeographic theories, supported by significant data, predict that half of all present species may be extinct within the next 100-300 years due to climate change, 
pollution, over-harvesting, habitat fragmentation and loss (Chapin et al. 2000; Jackson 2008; Costello and Wilson 2011). It is often claimed that extinction rates are on the increase both on land and in the oceans (Carlton et al. 1999; Dulvy et al. 2003; Costello and Wilson 2011), and that chances are good that species might go extinct even before a formal description (Costello et al. 2013a, b). Boero et al. (2013) stressed how well documented marine extinctions usually concern conspicuous species (e.g., the Caribbean monk seal Monachus tropicalis, the great auk Pinguinus impennis, and the Steller's sea cow Hydrodamalis gigas), and that the number of proven marine extinctions is very low, if compared with the alarming predictions of most review. This is not due to lack of extinction risks but, instead, to poor knowledge of the conservation status of most species (Roberts and Hawkins 1999; Régnier et al. 2009). Boero et al. (2013), however, claimed that the analysis of the history of the records of each species in space and time might be conducive to roughly assess their state of conservation.

Changes in both the abundance and the distribution of species commonly happen due to the arrival of new species, the rarefaction of common species, or the increase in the abundance of formerly rare species (Boero 1994, 1996; Bonsdorff et al. 1997). These changes are a natural feature of all systems but the rate of change can become alarmingly fast (Boero and Bonsdorff 2007). Biotic assessments are increasingly carried out to detect NIS (Gravili et al. 2013; Katsanevakis et al. 2013), and might be used also for the purpose of testing hypotheses of putative extinctions.

The aim of this paper is to review the knowledge of the diversity of Mediterranean NonSiphonophoran Hydrozoa (NSH), to detect species that are absent since decades, the "missing species", so as to assess current estimate of the species pool-size and raise cases of either regional or local extinction.

\section{Methods}

The choice of 41 years as a threshold to consider a species as missing was decided based on the rather intense study of hydrozoan species in the Mediterranean in the last four decades, with the establishment of the Hydrozoan Society in 1985 (Boero 2007) that gathered a rather substantial scientific community focusing on the Mediterranean. Due to intensive sampling, thus, if a previously reported species fails to be recorded chances are good that, at least, it is more rare than before. The knowledge about each species is stored in the scientific literature. Every known species has been described in a taxonomic paper, and the date of its first finding is the beginning of the history of its knowledge. The type locality is the centre of origin of that species, even though it might not be representative of the core of its actual distribution. After the original description, species are usually recorded again in other taxonomic, faunistic, or ecological papers. Analyzing the temporal and spatial distribution of species, as recorded by the scientific literature, we can reconstruct maps of their recorded presence in both space and time. We examined current estimates of the size of the Mediterranean species pool, to detect species that might have gone locally or regionally extinct. Picard (1958a) produced the first modern list of Mediterranean NSH. Since then, the number of species almost doubled due to addition of new records to the new ones. To assess the current state of the Mediterranean species pool with the state of the fifties, we compared Picard's list with the list of the species recorded in the last decade.

Our list of non-Siphonophora Hydrozoan "Missing" species (NSHMs) of the Mediterranean Sea is based on a recent monograph (Bouillon et al. 2004), on taxonomic revisions (e.g. Schuchert 2007, 2008a,b, 2009, 2010), and on an assessment of Mediterranean 
NSH (Gravili et al. 2013). To determine historical series and distributions, we consulted 749 faunistic studies published between 1850 and 2014. A database with 8,158 records was organized so as to provide the following information: species, family, author, life-cycle phase, reproductive state, location, date of collection e/o year of publication of the article, water depth, substrate type, synonymy, and cited references. Taxonomic records (i.e. records of each taxon, in any kind of report) are reported on a time scale from the original description to the last citation in the literature. The number of faunistic articles on Mediterranean Hydrozoa since 1850 was organized by decade (Fig. 1). The total number of articles (within the same time range) was then referred to each biogeographic sectors (A-M) identified by Bianchi (2007) (Fig. 2).

We identified NSHMs (not recorded since 41 years or more) examining records from the nineteenth century to 2014, to trace the origin, first and last Mediterranean records, current Mediterranean distribution, and global distribution of each species. With few exceptions, we named taxa according to Bouillon et al. (2006). The date and location of the first observation of each NSHMs in the Mediterranean Sea were extracted from the literature. Whenever possible, the actual date of first record was reported, along with its publication date, since the two dates coincide only in a few cases. Strauss and Sadler (1987, 1989) introduced the confidence of extinction index in paleobiology (Marshall 1990), as a method to calculate confidence intervals within local stratigraphic ranges. Boero et al. (2013) adapted this method to analyse cases of putative extinction in recent species. The confidence of extinction index was calculated for each species uncited since 41 years by using the following formula on historical taxonomic data:

$$
C=1-(G / R+1)^{-(H-1)}
$$

$\mathrm{C}$ is the confidence of extinction, $\mathrm{G}$ is the number of years since last sighting, $\mathrm{R}$ is the number of years between original description and the last sighting, $\mathrm{H}$ is the number of individual years in which there is a record, $\mathrm{C} \geq 95 \%$ postulates a case of extinction; $80 \% \leq \mathrm{C} \leq 94 \%$ raises a case of putative extinction.

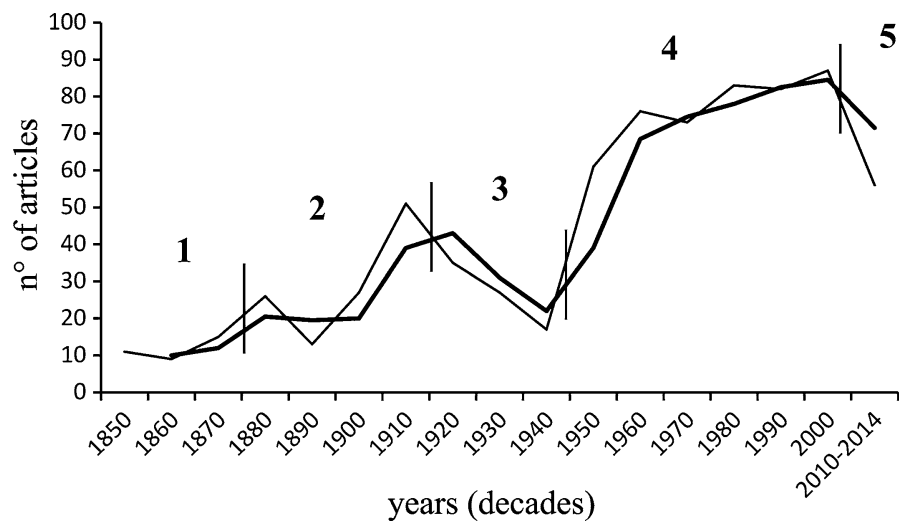

Fig. 1 Number of total articles about Mediterranean Hydrozoa since 1850-today by decade: general trend (thin line), with mobile average over 2 year periods (thick line). Vertical lines separate five main periods within the trend 


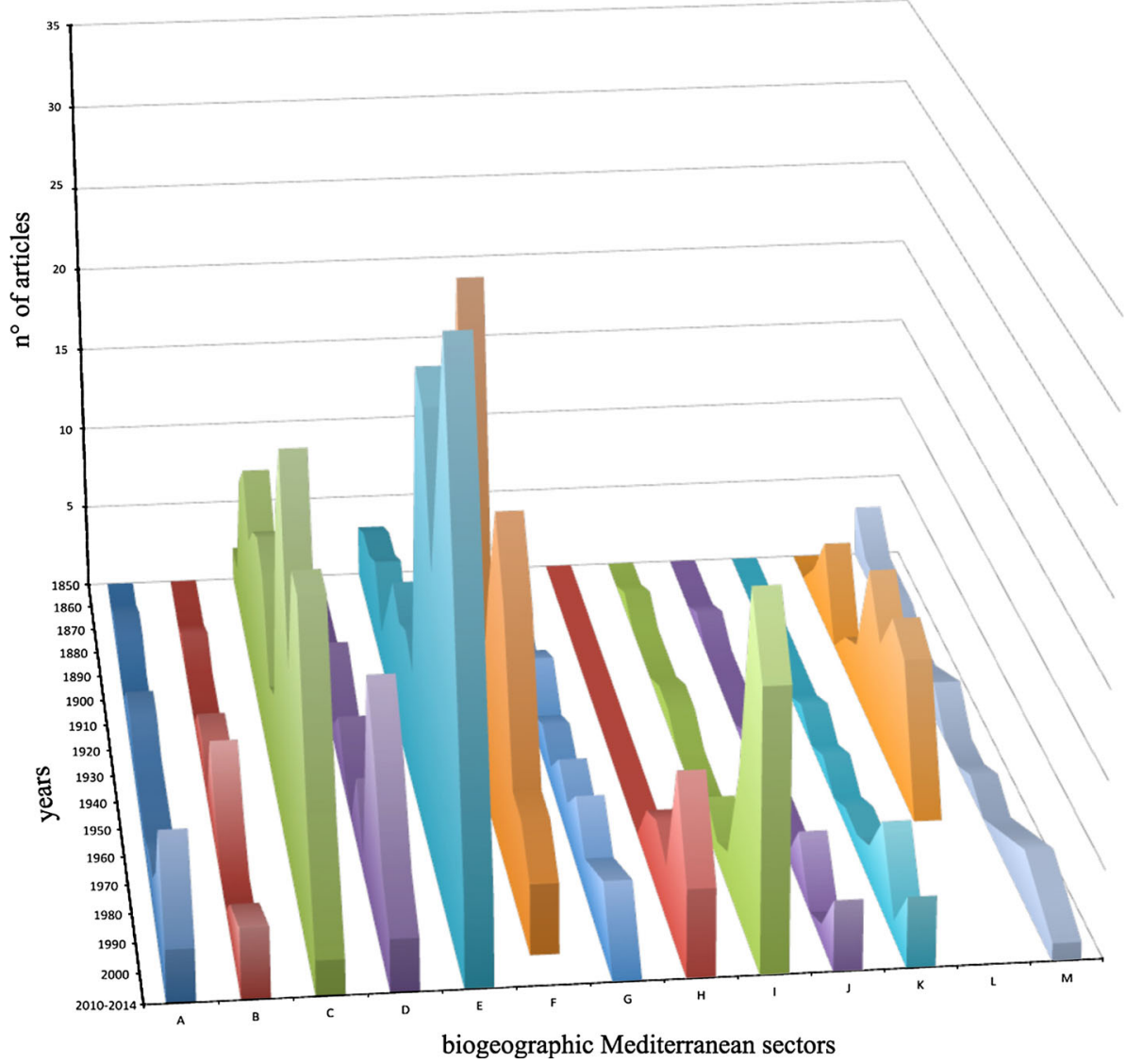

Fig. 2 Number of articles that include faunistic studies about Mediterranean Hydrozoa since 1850-today by decade for biogeographic sectors (A-M) according to Bianchi (2007). See map legend (Fig. 3) for abbreviations

All records were organized in a presence/absence data matrix of species (NSHMs included) in each biogeographic sector (A-M) for each historical period [ $>40$ years ago ( $>40$ years), from 40 to 31 years ago (40 years), from 30 to 21 years ago (30 years), from 20 to 11 years ago (20 years), and from 10 years ago to nowaday (10 years)]. A distance matrix based on Jaccard's distance among sector $\times$ period centroids was then obtained. A canonical analysis of principal coordinates (CAP) (Anderson and Robinson 2003; Anderson and Willis 2003) based on the distance matrix was then performed for the factor period, in order to portray temporal changes in the whole Mediterranean species pool of NSH. Distinctness among locations was assessed using leave one-out allocation success (Anderson and Robinson 2003). Species most contributing to group differences in the CAP plot were investigated by calculating product-moment correlations $(r)$ of original variables (species) with canonical axes (Anderson and Willis 2003). Only species with correlation values exceeding an arbitrarily chosen value of correlation $r \geq 0.2$ were considered.

The 'average taxonomic distinctness' $\left(\Delta^{+}\right)$(Clarke and Warwick 1998) and 'variation in taxonomic distinctness' $\left(\Lambda^{+}\right)$(Clarke and Warwick 2001), complementing $\Delta^{+}$, were employed to explore temporal changes in the taxonomic structure of NSH species pool in 
the whole Mediterranean basin. $\Delta^{+}$represents the average taxonomic path length between two randomly chosen species in the taxonomic tree, whereas $\Lambda^{+}$reflects the unevenness in the taxonomic tree of a given species' list and represents the variance of these pair-wise path lengths. The indices are independent of the number of species in a sample and thus represent useful tools for analysing historical data (Bevilacqua et al. 2009). A reference list, from species to subclass, was made including all NSH species recorded. The list coupled with the presence/absence data matrix was used to calculate the values of $\Delta^{+}$and $\Lambda^{+}$of Mediterranean NSH species pool in each period. The same step length (equal to 1) was used in weighting all distances between hierarchical taxonomic levels (Clarke and Warwick 1999). For both taxonomic distinctness indices, the $95 \%$ confidence funnel was generated (Clarke and Warwick 1998, 2001) in order to test temporal departures from expectations of $\Delta^{+}$and $\Lambda^{+}$(under the null hypothesis that the species pool in each period was a random subsets of the full NSH species list).

\section{Results}

The updated list of NSH species, after an accurate systematic revision, sums up to 398 species, representing about $11 \%$ of the 3,702 nominal known species of the superclass Hydrozoa reported by Bouillon et al. (2006). The species recorded from the Mediterranean Sea in the last decade sum up to 162, and 118 of them (73\%) are present in Picard's (1958a) list of 191 species (180 valid species if cleaned up by synonyms); 53 species $(13 \%)$ are not recorded in the literature since at least 41 years (Table 1).

The assessment of the status of the unrecorded NSHMs with the Confidence of Extinction Index $(\mathrm{C})$ shows that 32 species $(60 \%)$ have $\mathrm{C} \geq 95 \%$ so representing cases of extinction; 30 of these have $\mathrm{C}$ equal to $100 \% ; 6$ species $(11 \%)$ have $80 \% \leq \mathrm{C} \leq 94 \%$ and represent cases of putative extinction; the remaining 15 species $(28 \%)$ have $\mathrm{C}<80 \%$. The largest contingent of the missing species is endemic to the Mediterranean (18 species, $34 \%$ ), followed by boreal ones (10 species, $19 \%), 15 \%$ (8 species) is MediterraneanAtlantic; the Indo-Pacific and circumtropical contingents are represented by 6 species each (11\%), followed by the cosmopolitan contingent ( 2 species, $4 \%$ ), 1 tropical-Atlantic species (2\%), and $4 \%$ (2 species) are non-classifiable.

Of the 18 endemic NSHMs of Mediterranean Sea, 10 have $\mathrm{C} \geq 95 \%$ so representing cases of extinction (Merga galleri, Acauloides ilonae, Staurocladia portmanni, Branchiocerianthus italicus, Coryne caespes, Siphonohydra adriatica, Melicertissa adriatica, Eucheilota maasi, Plumularia syriaca, Cunina polygonia), the remaining eight ones (Lizzia octostyla, Tregoubovia atentaculata, Coryne fucicola, Hydranthea aloysii, Orchistomella graeffei, Octogonade mediterranea, Tiaropsidium mediterraneum, Cunina proboscidea), having $80 \% \leq \mathrm{C} \leq 94 \%$, represent cases of putative extinction (see Table 1).

Moreover, there are difficulties to assess the validity of several NSHMs. It is the case, for example, of $S$. adriatica whose gonophores, as well as the fully-grown animal, remain unknown (for more details see Schuchert 2010). Kramp (1961) reported another case, where Picard (1958a) refers doubtfully M. adriatica to the Tiaropsidae as O. mediterranea Zoja 1896. Hydranthea aloysii is an insufficiently described species that could be any haleciid or lovenelliid (Bouillon et al. 2004). Bougainvillia multicilia is considered a doubtful species (see Kramp 1955; Schuchert 2007). Schuchert (2007) retained that new Mediterranean material is needed for a further evaluation of the status of the species Amphinema turrida. Concerning the species Protiara tetranema, recorded by Pell $(1918,1938)$ from the Adriatic 


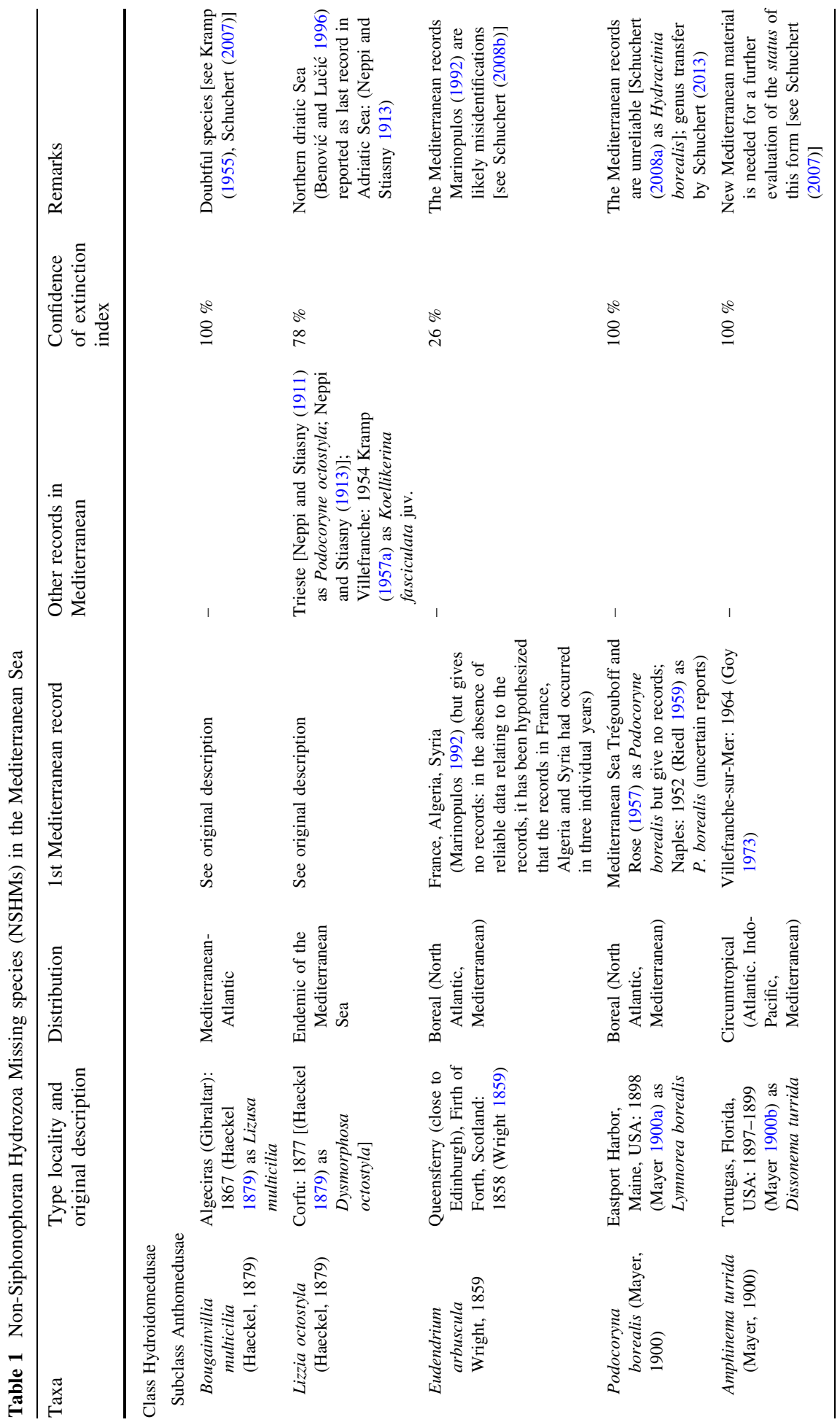




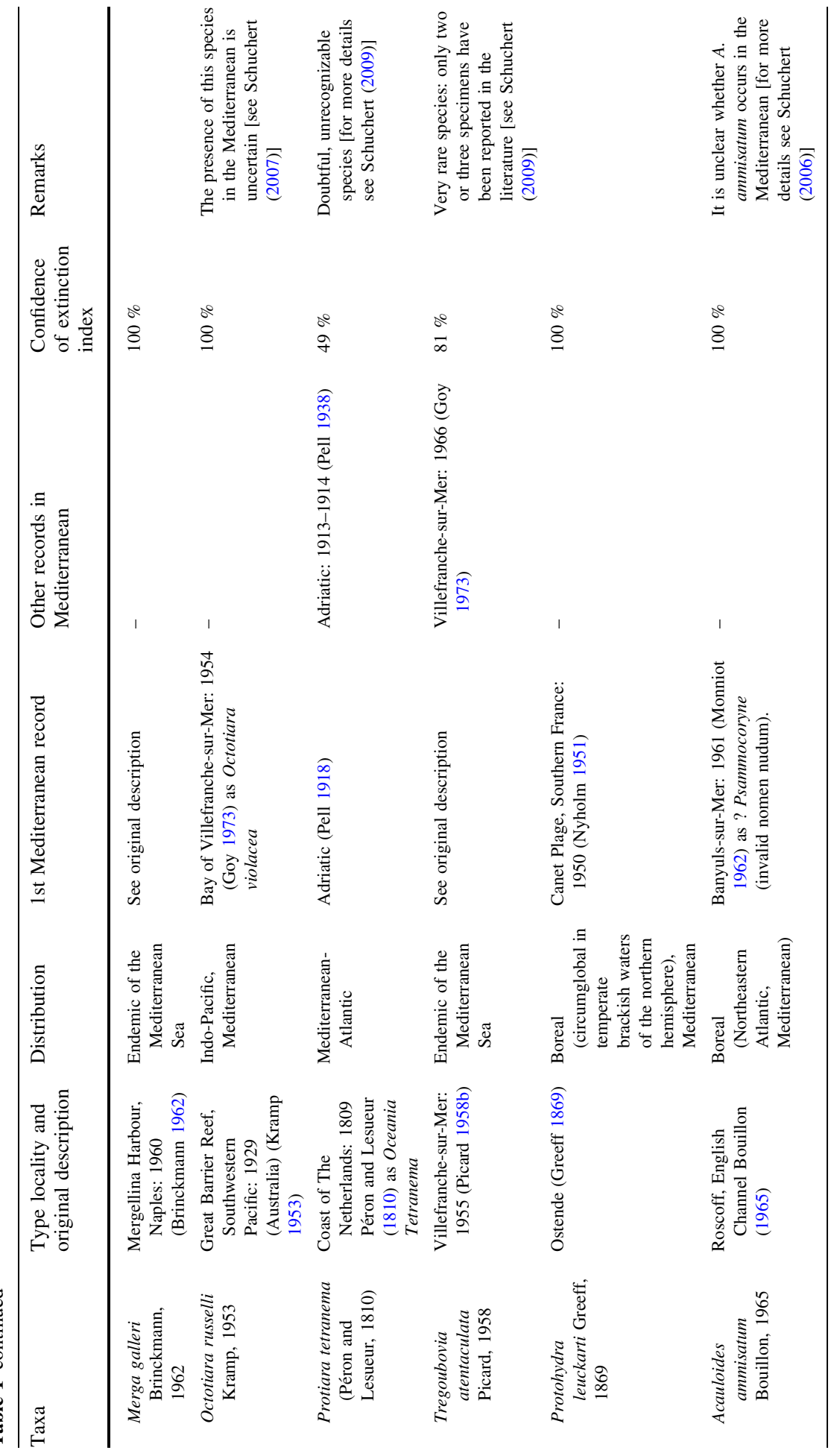




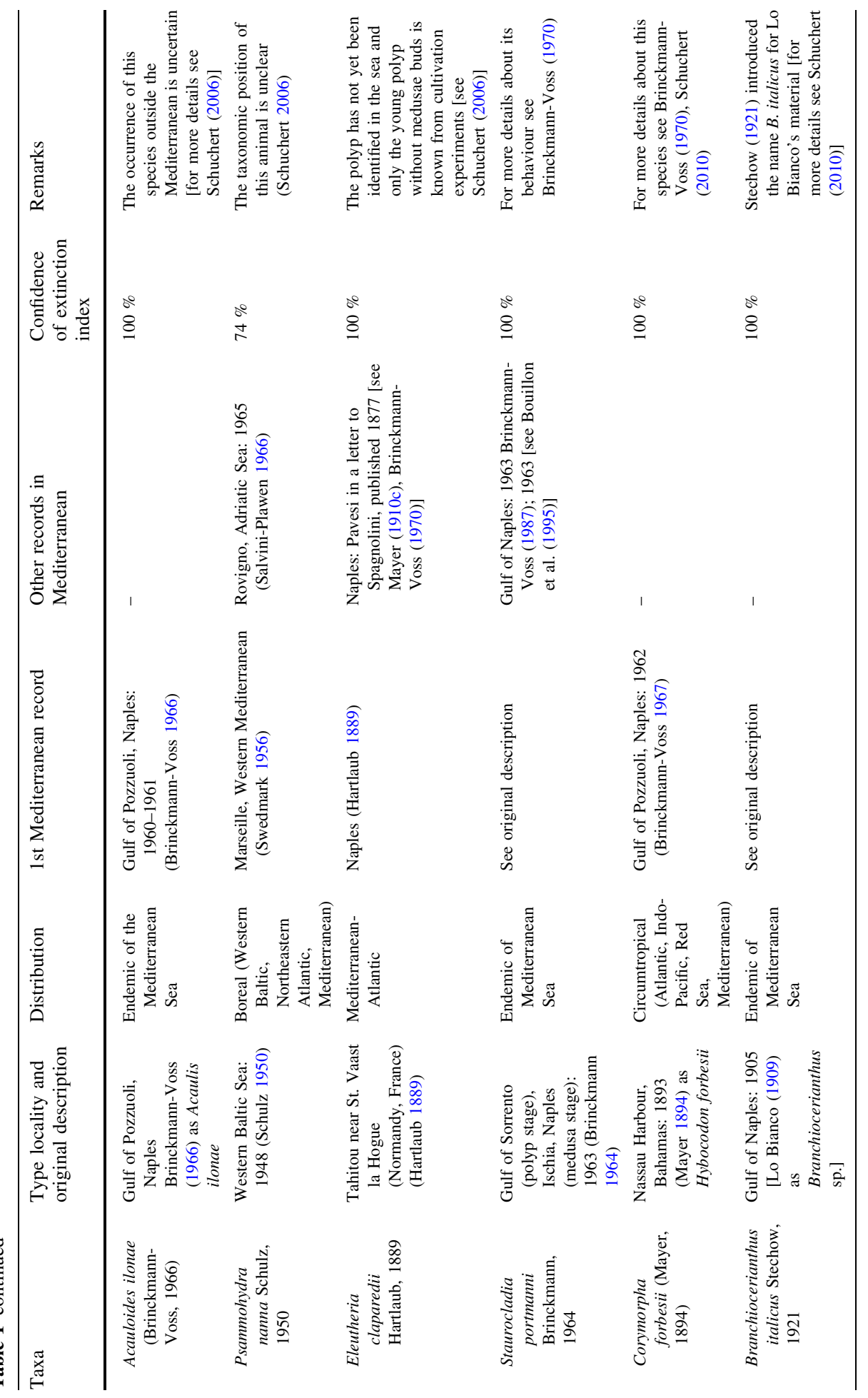




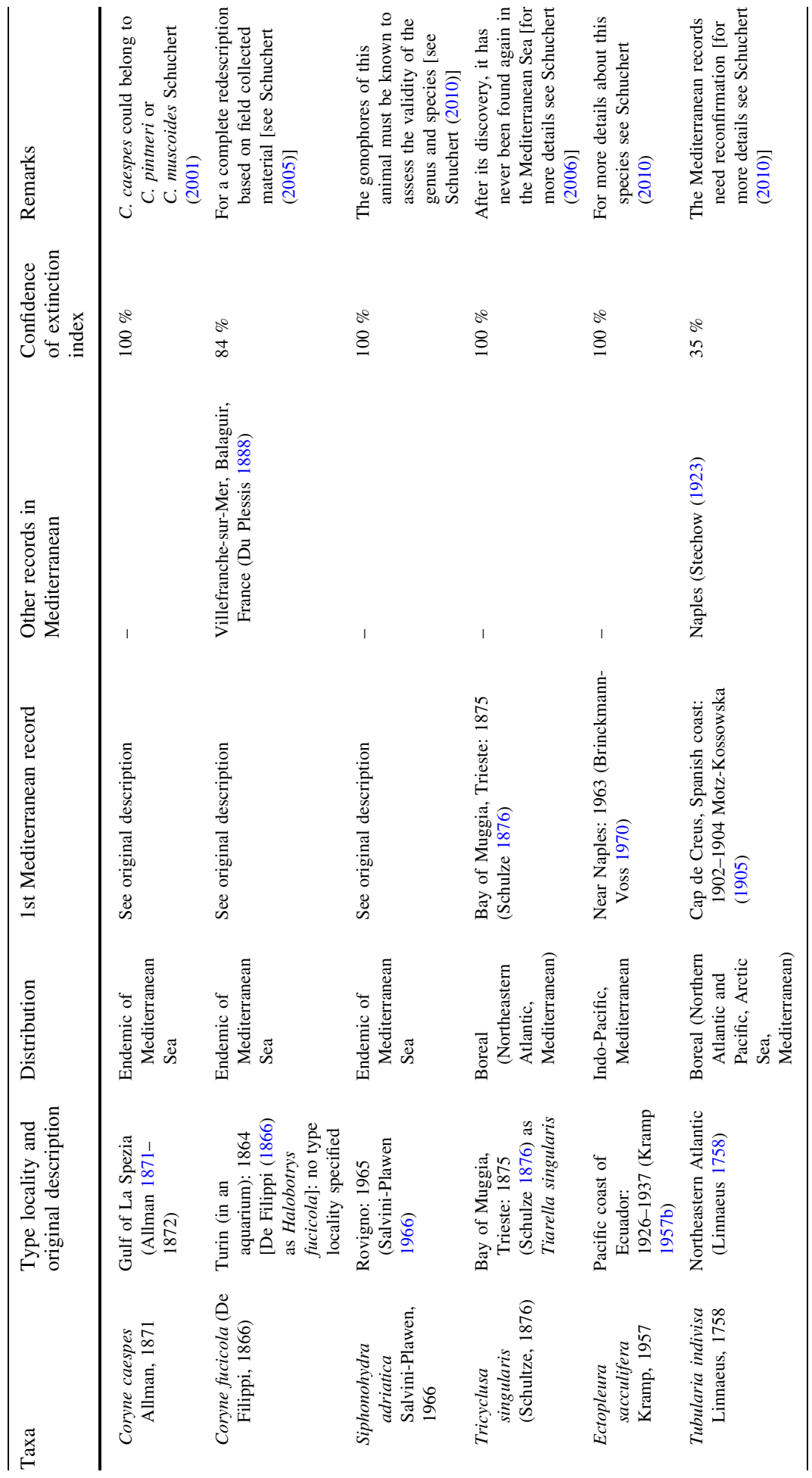




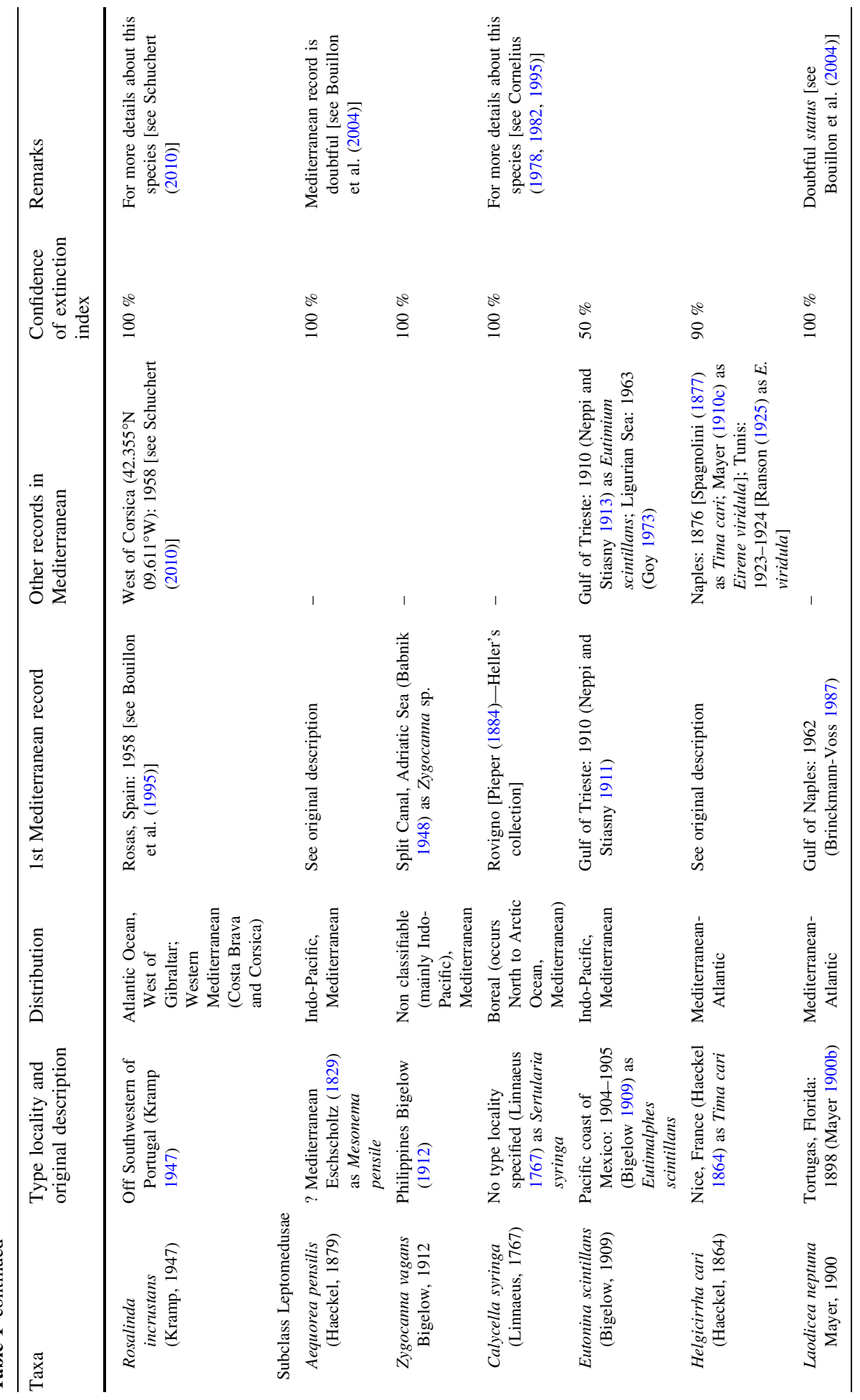




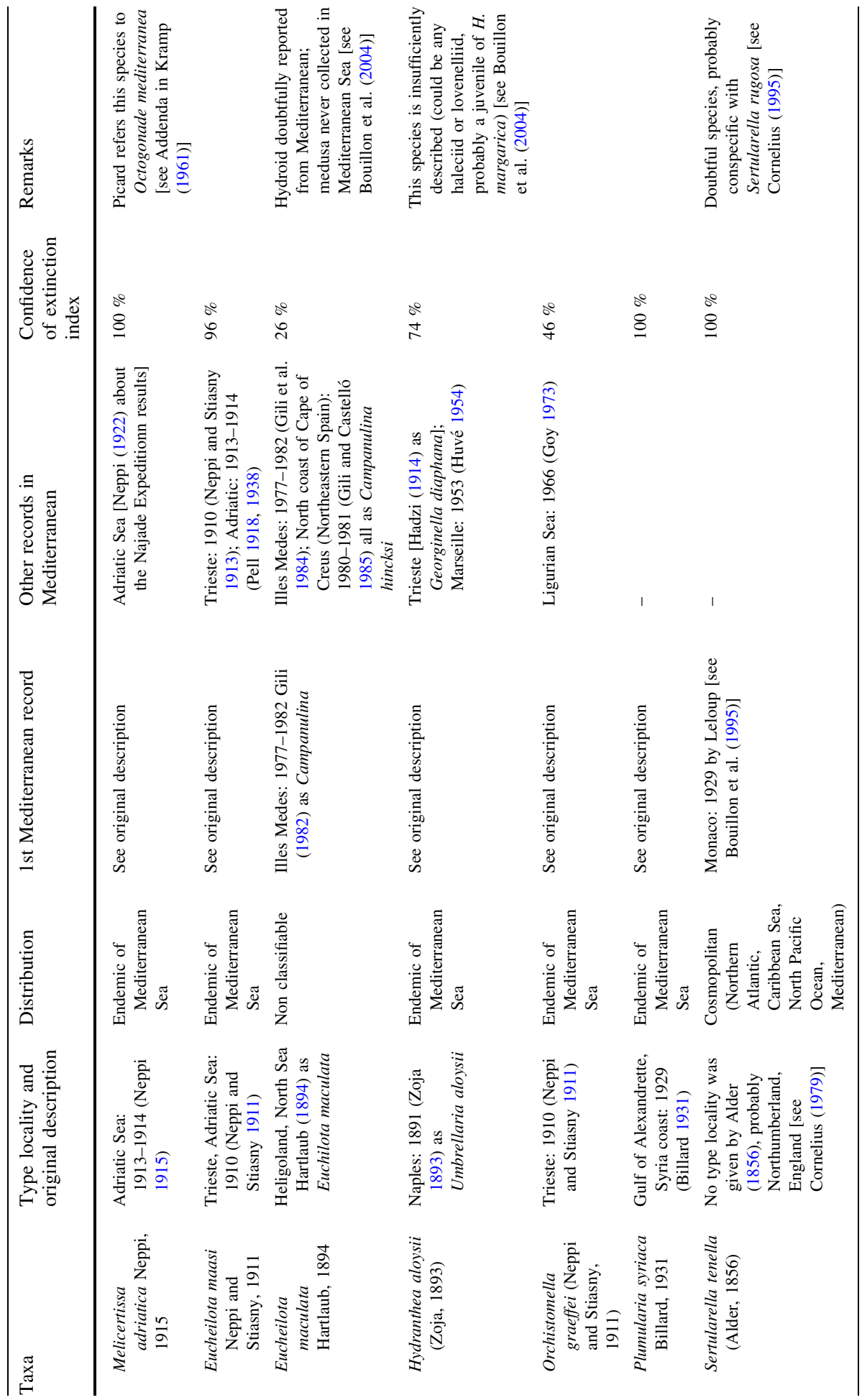




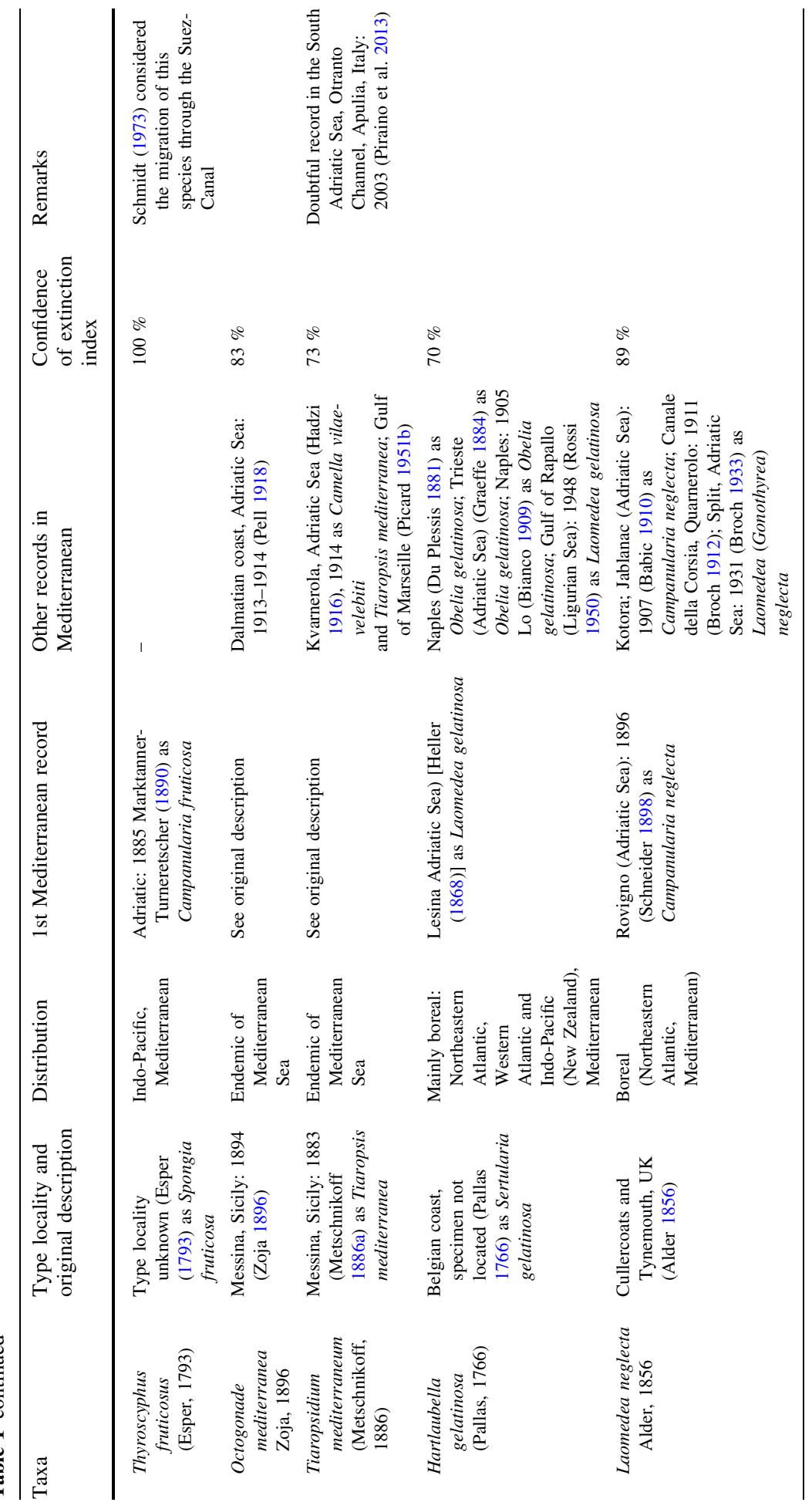




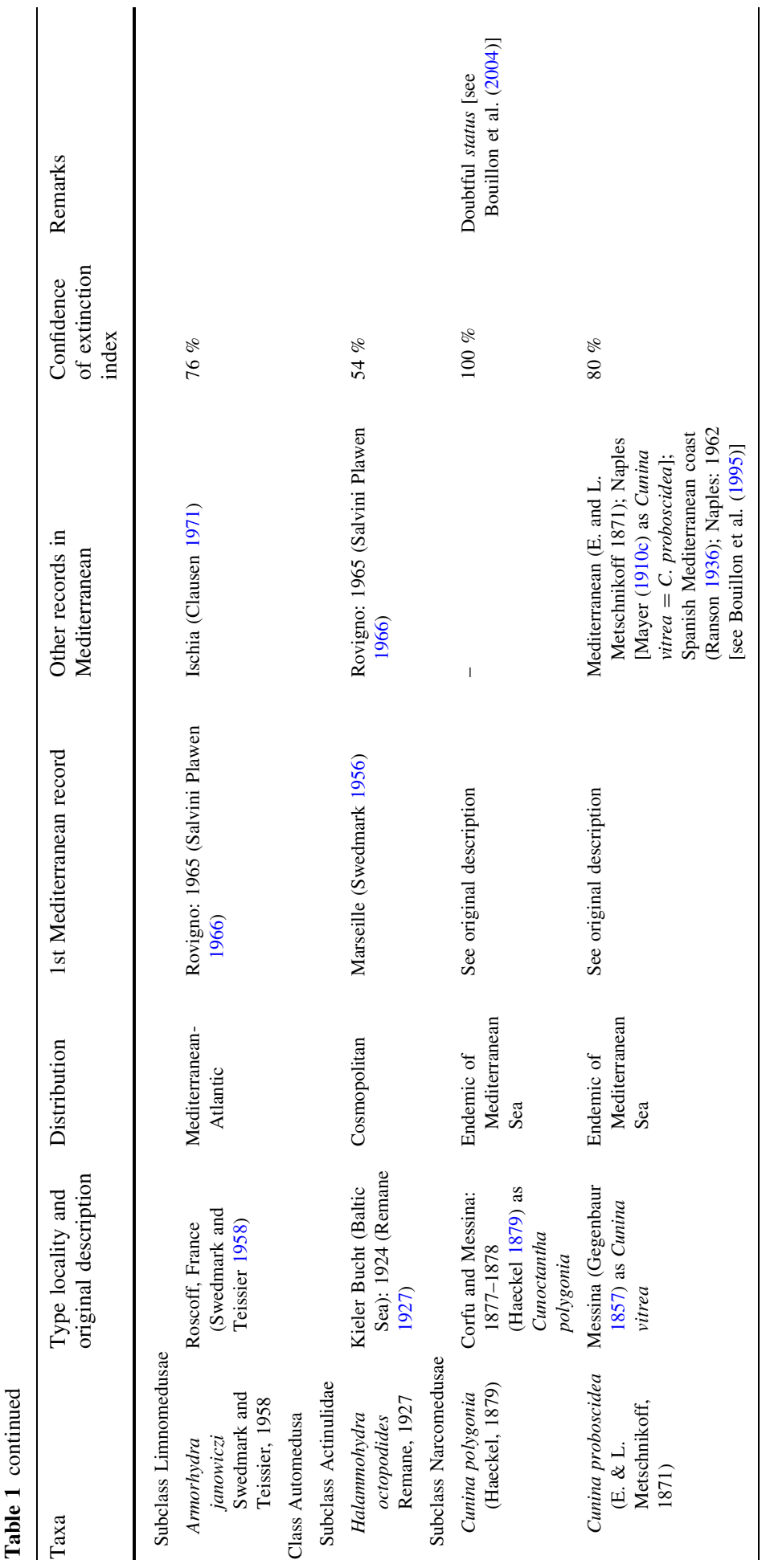




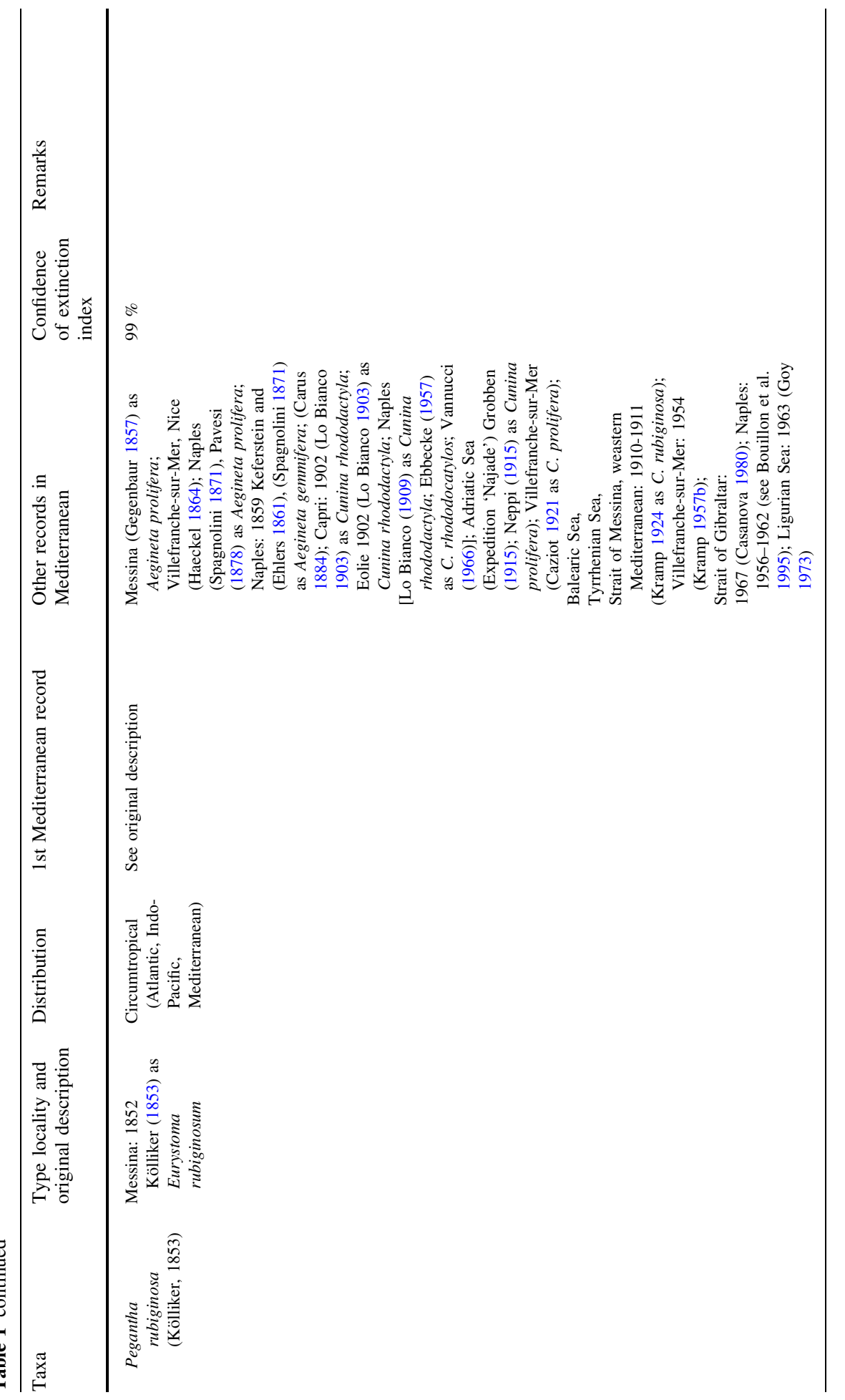




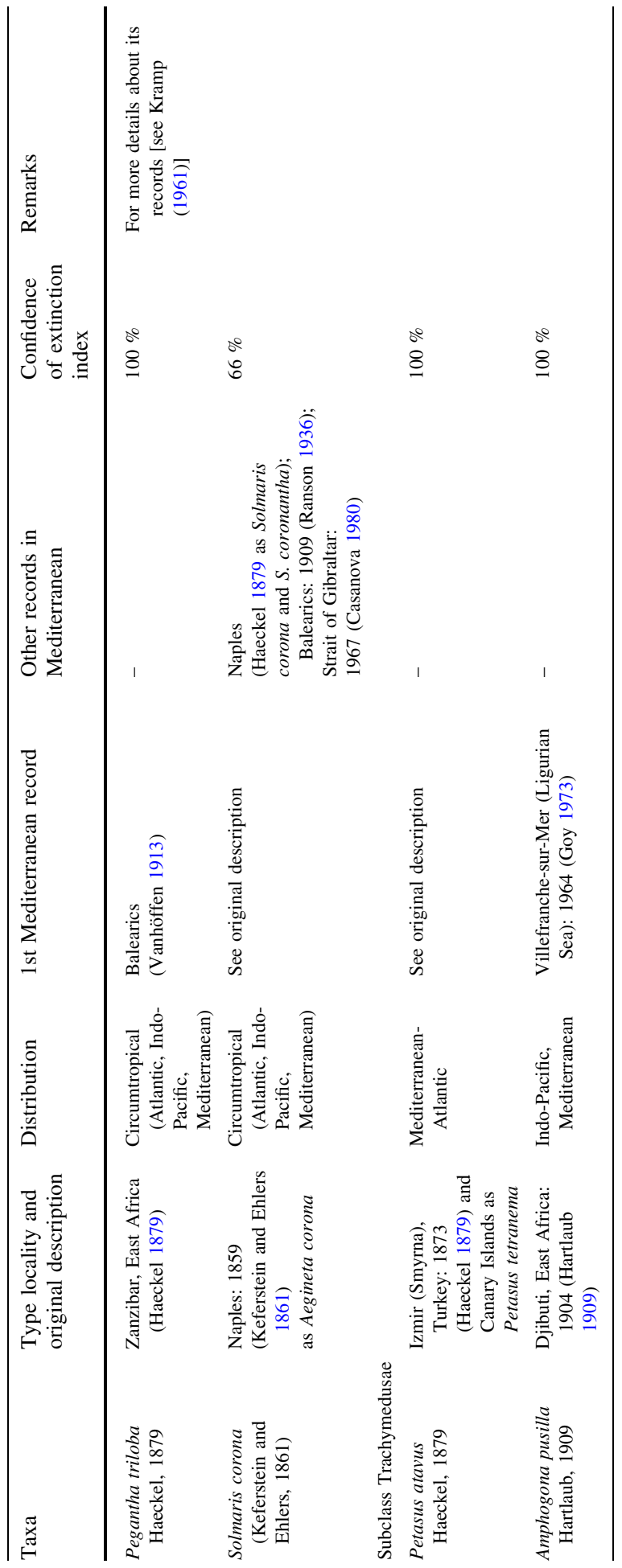




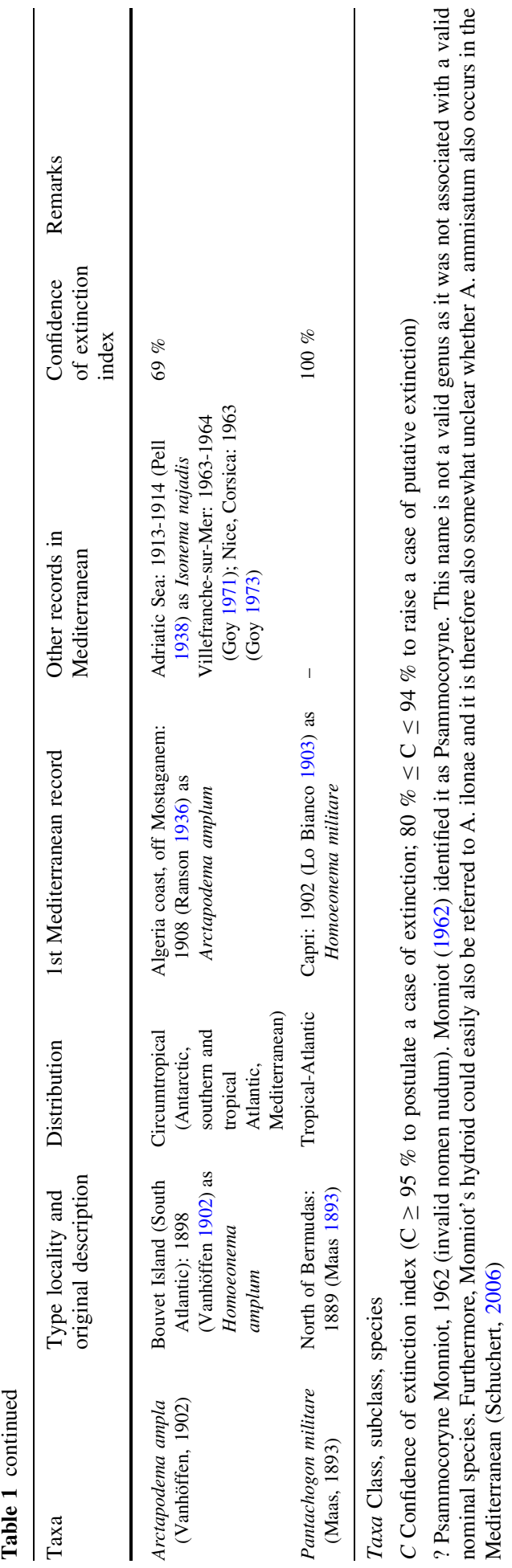


Sea, based on unclear criteria, Schuchert (2009) suggested that it is a doubtful, unrecognizable species. Finally, Bouillon et al. (2004) listed C. polygonia as doubtful.

Uncertain records concern species as Eudendrium arbuscula, whose Mediterranean records are likely misidentifications (Schuchert 2008b); the records of Podocoryna borealis are unreliable according to Schuchert (2008a). The presence of Octotiara russelli in the Mediterranean Sea is uncertain. Goy (1973) published the only European record of this species, as Octotiara violacea, but this reporting should be re-examined due to the state of preservation of the specimen that impedes certain identification (Schuchert 2007). Tiaropsidium mediterraneum was recorded for the first time in Messina (Metschnikoff 1886a) as Tiaropsis mediterranea, whereas its record in the South Adriatic (see Piraino et al. 2013) is doubtful.

Moreover, particular problems are related to records of the micro-meiobenthos NSH species that might be underestimated due to paucity of research in this field, namely: Acauloides ammisatum (whose presence in Mediterranean Sea is unclear; see Schuchert 2006), A. ilonae, Psammohydra nanna (whose taxonomic position is unclear; see Schuchert 2006), Armorhydra janowiczi, and Halammohydra octopodides. A particularly significant example of species that is absent since a very long time is Tricyclusa singularis (Schulze 1876). This species of boreal affinity and, since its original description from Trieste, the sole Mediterranean record, it has never been recorded again from the Mediterranean Sea. Its disappearance represents not only a case of Mediterranean extinction of a species, but also of the whole family Tricyclusidae that comprises only this species and genus (Boero and Bonsdorff 2007).

Studies of the Mediterranean Hydrozoa suffered several temporal gaps during the considered period (Fig. 1). The whole trend, expressed in number of papers per decade, can be divided into five periods, marked by changes in the patterns of scientific production (Fig. 1):

- 1850s-1870s, with an average of over 10 papers/decade;

- 1880s-1910s, with an average of about 30 papers/decade: about 20 papers/decade in the sub-period 1880s-1890s, and about 40 papers/decade in 1990s-1910s, with an increase of scientific production until a peak in the 1910s (51 papers) followed by a sharp decrease due to First World War;

- 1920s-1940s, (average of over 25 papers/decade) with a marked decrease coinciding with Second World War;

- 1950s-2000s, with an average of almost 80 papers/decade;

- 2010s-2014s, with an average of about 55 papers/decade, but monitoring of the entire decade (2010-2020) is still incomplete.

Figure 2 shows that since the 19th century many studies were carried out at the Zoological Station of Naples (biogeographic sector C). Messina also attracted high attention (biogeographic sector M), due to the strong currents of its Strait characterized by animals of deep waters. Kölliker (1853), Keferstein and Ehlers (1861), Metschnikoff (1886a, b), worked extensively at Messina contributing to the knowledge of the Hydrozoa. Other Mediterranean places where research on Hydrozoa became prominent were Trieste and Rovinj (biogeographic sector F), Split (biogeographic sector G) and, in France, Villefranche-sur-Mer, Endoume, and Banyuls (biogeographic sector E). In particular, a long series of papers mainly by Picard (1951a,b, 1958b) and Goy (1973) gave a great contribution to the knowledge of the Hydrozoa. Moreover, between the years 1960s and $1970 \mathrm{~s}$ several researchers (among these, Bouillon, Brinckmann-Voss, Haeckel, Tardent, Uchida, 
Vannucci, Yamada) worked at the Naples Zoological Station to describe the life cycles of Hydrozoan species.

Numbers of Non-Siphonophoran Hydrozoa Missing species (NSHMs) in each biogeographic sector within the Mediterranean Sea is shown in Fig. 3 reporting percentages of missing species/total number species for each sector. It is clear that the highest percentage of disappearance is linked to the colder biogeographic sectors of the Mediterranean basin: $11 \%$ in the deep waters of the Strait of Messina (biogeographic sector M), $8 \%$ in the Gulf of Lions and Ligurian Sea (biogeographic sector E), $7 \%$ both in the Northern and Central Adriatic Sea (respectively, biogeographic sectors F and G).

CAP analysis showed a clear separation of points of $>40$ years (left down corner of the plot) from those of 10 years (right down corner), with intermediate position of points of 40, 30, and 20 years (Fig. 4), indicating a temporal gradient of species composition of NSH in the Mediterranean. A total of $171 \mathrm{NSH}$ species showed a correlation value $>0.2$ with canonical axes, the $35 \%$ of them being NSHMs $(20 \%)$ or NIS $(15 \%)$.

Results form analyses on taxonomic distinctness highlighted a decrease of both $\Delta^{+}$and $\Lambda^{+}$of the Mediterranean NSH species pool through time (Fig. 5). The species pool of $>40$ y showed significantly higher values $(P<0.05)$ of $\Delta^{+}$and $\Lambda^{+}$, indicating a higher breadth and heterogeneity of taxonomic structure. In contrast, the species pool in the last decade (10 years) exhibited values of $\Delta^{+}$and $\Lambda^{+}$significantly below random expectation, indicating that Mediterranean NSH species were more closely related than expected by chance, with a significant reduction of taxonomic distinctness (Fig. 5).

\section{Discussion}

The scarcity of well-documented cases of extinction in the marine environment shows how difficult it is to deal with the conservation status of marine invertebrates (Boero et al. 2013).

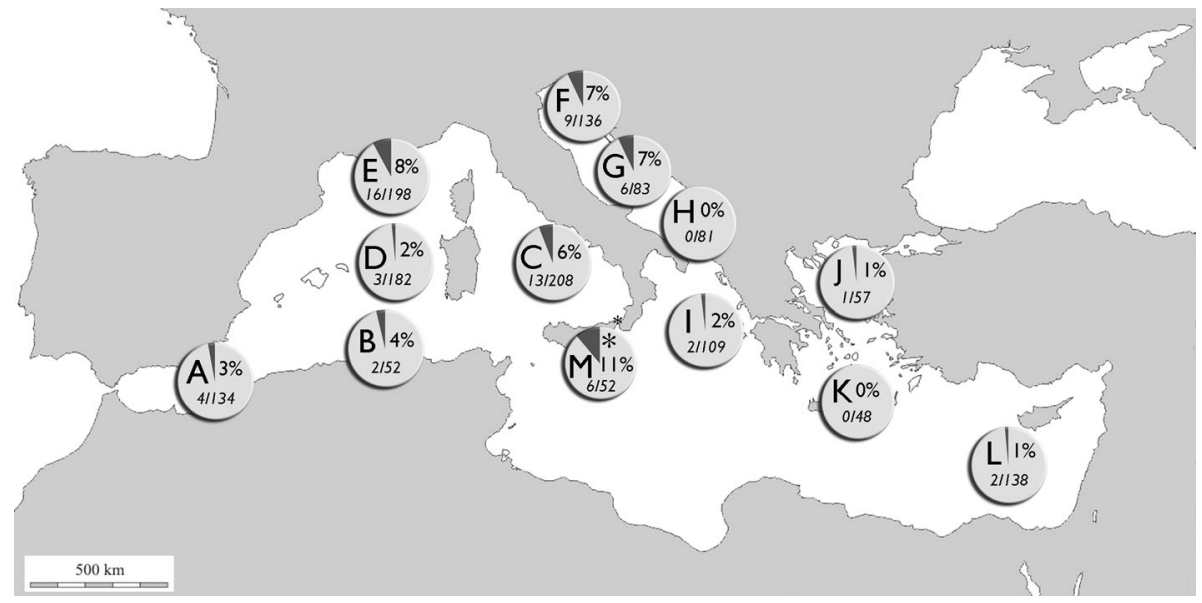

Fig. 3 Disappearance of Non-Siphonophoran Hydrozoa Missing species (NSHMs) within the Mediterranean Sea. a Alborán Sea; b Algeria and North Tunisia coasts; c Southern Tyrrhenian Sea; d Balearic Sea to Sardinia Sea; e Gulf of Lions and Ligurian Sea; f Northern Adriatic; $\mathbf{g}$ Central Adriatic; $\mathbf{h}$ Southern Adriatic Sea; i Ionian Sea; j Northen Aegean Sea; k Southern Aegean Sea; l Levant Sea; m Strait of Messina (marked by asterisk). Biogeographic sectors according to Bianchi (2007). For each sector, NSHMs percentage and NSHMs number/non-Siphonophoran Hydrozoa (NSH) total number are shown 


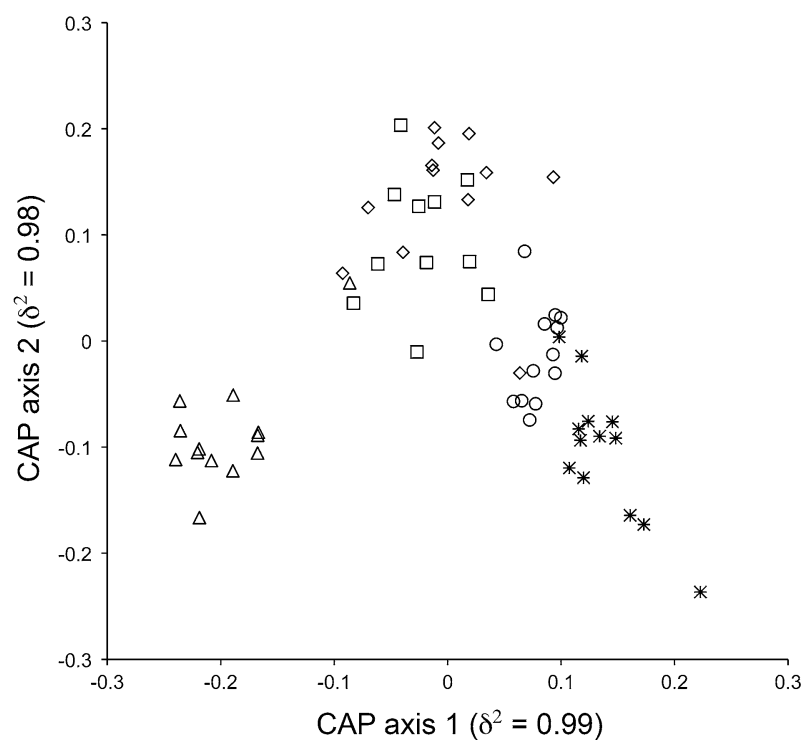

Fig. 4 Canonical analysis of principal coordinates (CAP) for the factor period based on the distance matrix (Jaccard's distance) among sector $\times$ period points. Open triangle $>40$ years, open diamond 40 years, open square 30 years, open circle 20 years, asterisk 10 years

Boero and Bonsdorff (2007) wondered if this is the consequence of low global risks of extinction in the sea or, rather, if we fail to notice that species become extinct. According to Roberts and Hawkins (1999), there might have been numerous extinctions in recent times that we failed to realise. Fontaine et al. (2007) addressed the problem of the current indicators that do not cover the species at risk of extinction, as most of rare species are not considered in the European Union's 2020 target. Alternative indicators about rare species must be developed, in addition to the existing ones that provide information on biodiversity trends (Butchart et al. 2005; De Heer et al. 2005). Indeed, the choice of indicator species should be expanded through a rigorous assessment based on various parameters which take into account also rarity (Fontaine et al. 2007). Moreover, the fundamental question is how soon such changes will occur (Hughes 2000), as well as the particular time ranges chosen for the data sets can greatly affect apparent trends (Hughes 2000). Carlton et al. (1999) observed that the processes of species extinction run at different paces, involving several mechanisms working at different spatial scales. In general, the three main changes in response to environmental stress of the marine communities consist in regression to dominance by opportunist species, reduction of the dominating species resulting in lower diversity (Pearson and Rosemberg 1978; Gray 1989). The features of species that have gone extinct or are nearly extinct (population turnover, reproduction, capacity for recovery, range and distribution, commonness and/or rarity, trophic level) often contribute to their disappearance (Dayton et al. 1995; Roberts and Hawkins 1999).

The Mediterranean Sea is predisposed to local extinction because it is almost closed and much smaller than the open ocean, responding more quickly to environmental change and, furthermore, has a high rate of endemism (Boero and Gravili 2013). This sea is characterized by a particular biota made of highly seasonal species, tropical and boreal 
contingents being present respectively in the summer, and in the winter (Bavestrello et al. 2006). The Mediterranean marine ecosystem, being subjected to a period of temperature increase that is tropicalizing its biota, represents a model basin for oceans and other seas (Bianchi 2007; Boero and Bonsdorff 2007; Lejeusne et al. 2010).

It is very difficult to confirm the disappearance of a species in the marine environment, mostly due to lack of taxonomist and the existence of synonyms in the species lists (different names attributed to the same species). Therefore, simple lack of suitable sampling or of expertise in recognizing synonyms in previous samplings, might determine their absence from subsequent records. It is debatable whether lack of records is due either to changing of abiotic or biotic factors, or to low sampling efforts or, eventually, to the combination of these causes. Surely, the Mediterranean Sea is going through a radical change that is almost unparalled in respect to any other part of the world (Boero 2014; Templado 2014).

The absence of a species, furthermore, might be only apparent, due to the existence of resting stages that can remain dormant for long periods and that, when activated, are responsible for the so-called "Lazarus effect" (Jablonsky 1986).

As expected by Boero et al. (2008), global warming is favouring the tropical contingent, whereas the boreal one is in distress. If global warming can damage species, the potential sufferers are Mediterranean endemic species (34\% of the NSHMs), those of cold water affinity $(19 \%)$ or Mediterranean Atlantic ones (15\%). Indo-Pacific and circumtropical contingents represent each $11 \%$ of the total NSHMs, extinctions in the Mediterranean being probably linked to lack of establishment of species that recently reached the basin. The results of this study confirm the trend characterized at a first time by the abiotic change, induced by increasing temperatures, and followed, at a later time, by biotic change, since the arrival of aliens of tropical affinity (Zenetos et al. 2012; Gravili et al. 2013; Çinar et al. 2014), or the prevalence of the summer contingent that competes against the species of cold water affinity (Puce et al. 2009).

The results of this study, as well as the data analyzed over the long term by Puce et al. (2009), suggest that the regional species pools tend to remain stable in terms of species numbers but not in terms of species identity. In fact, the number of present-day Mediterranean NSH species (162) matches closely the number of species (180 valid species) that Picard (1958a) recorded in his first assessment, cumulating all previous knowledge on the group. However, our finding showed that the composition of the species pool at basin scale changed through time, with changes heavily driven by NSHMs and NIS. Moreover, we detected a progressive contraction of the taxonomic width of NSH, imputable to the loss of taxa poor in species or monotypic, which raises concerns about potential ensuing depletion of taxonomic and functional diversity.

The tropical NIS, colonising the Mediterranean Sea, are probably filling the ecological spaces of species that are becoming rare or are locally extinct. Bianchi (2007) predicted that the northern areas of the Mediterranean Sea will be invaded by warm-water native species, while the southern areas of the basin will be occupied by tropical exotic species. Furthermore, the warming of the Mediterranean Sea might probably cause a decrement of native cold-water species, or even their disappearance (Bianchi 2007).

Boero et al. (2008) proposed the so-called 'cold engines' (the northernmost part of the Western Mediterranean, the Northern Adriatic, and the Northern Aegean) as the areas with greater probability of presence of putatively extinct species in a period of global warming. These places, the drivers of the vertical remixing of Mediterranean waters, are significantly colder than the rest of the basin. They are inhabited by many species of cold-water affinity. The compilation of lists of species for all significant taxonomic groups that live only in 

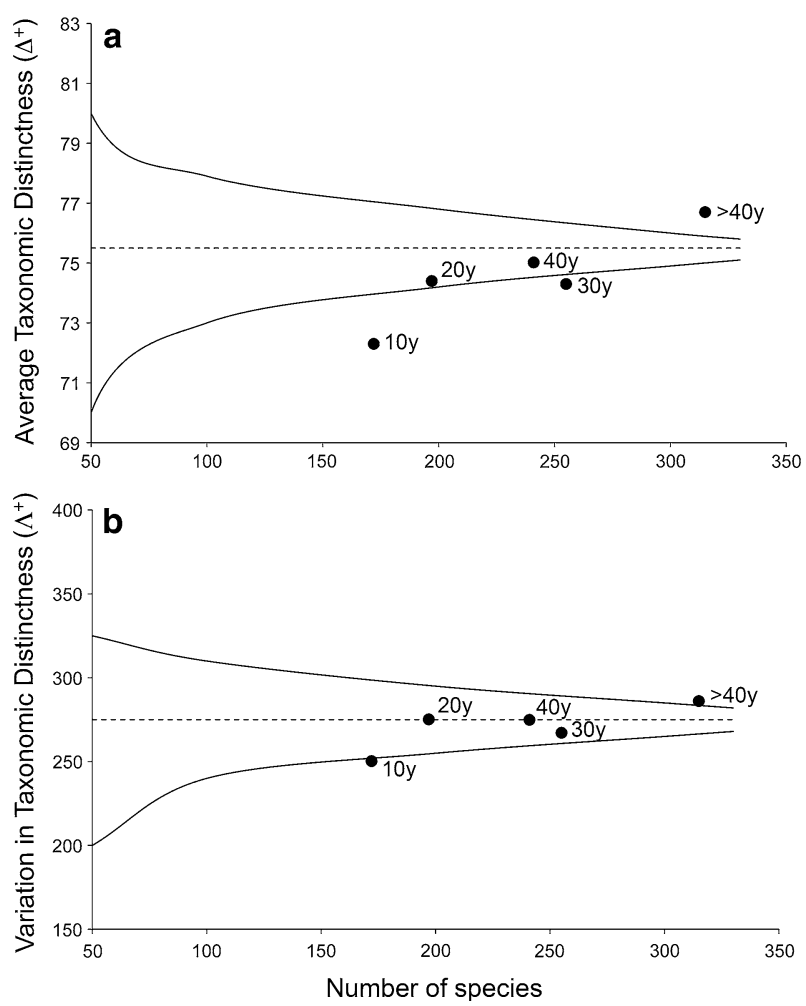

Fig. 5 Average taxonomic distinctness (a) and variation in taxonomic distinctness (b) of Mediterranean NSH species pool in each of the five periods ( $>40,40,30,20,10$ years) plotted against the corresponding total number of species characterizing each period. For both indices, the expected mean (dotted line) and the $95 \%$ confidence limits (solid lines) were also plotted from 1,000 independent simulations drawn randomly from the full list of Mediterranean NSH species

these areas might provide a tool for creating lists of putatively extinct species, and allow the programming of surveys to ascertain their conservation state (Boero and Gravili 2013). The results shown here suggest that species lists are dynamic, requiring continual updating (introduced species) and putative subtractions of missing species. Without these subtractions, biodiversity is always on the rise due to the arrival of NIS and the species lists will never show possible biodiversity crises at the level of species pools.

Mendelson et al. (2006) required an unprecedented conservation response to stop the loss of species and populations. The rates of marine species description, driven by the increasing ability to explore previously unknown geographic areas, have never been higher, as well as the challenge to estimate the diversity of cryptic species through molecular studies (Appeltans et al. 2012). The rapid influx of NIS and the disappearance of the species of cold-water affinity are heavily influencing the rich but vulnerable Mediterranean ecosystem, heavily affected already by a host of multiple impacts (Claudet and Fraschetti 2010; Boero 2014).

The application of the present analysis to all other taxa will allow for a better assessment of the state of biodiversity in all seas and oceans. 
Acknowledgments Work supported by Ministero dell'Università e della Ricerca Scientifica e Tecnologica (COFIN, PRIN and FIRB projects), by the CONISMA-CMCC project 'The impacts of biological invasions and climate change on the biodiversity of the Mediterranean Sea' and by the European Commission Seventh Framework Programme (FP7) projects 'Vectors of Change in Oceans and Seas Marine Life, Impact on Economic Sectors' (VECTORS), 'Towards coast to coast networks of marine protected areas (from the shore to the high and deep sea), coupled with seabased wind energy potential' (COCONET), and 'Policyoriented marine Environmental Research in the Southern European Seas' (PERSEUS). The publication of this paper is supported by CONISMA, the Italian National Interuniversity Consortium for Marine Sciences and the Flagship project RITMARE.

Open Access This article is distributed under the terms of the Creative Commons Attribution License which permits any use, distribution, and reproduction in any medium, provided the original author(s) and the source are credited.

\section{References}

Alder J (1856) A notice of some new genera and species of British hydroid zoophytes. Ann Mag Nat Hist 2(18):353-362

Allman GJ (1871-1872) A monograph of the gymnoblastic or tubularian hydroids. Ray Society, London

Anderson MJ, Robinson J (2003) Generalized discriminant analysis based on distances. Aust N Z J Stat 45:301-318

Anderson MJ, Willis TJ (2003) Canonical analysis of principal coordinates: a useful method of constrained ordination for ecology. Ecology 84:511-525

Appeltans W, Ahyong ST, Anderson G et al (2012) The magnitude of global marine species diversity. Curr Biol 22:2189-2202

Astraldi M, Bianchi CN, Gasparini GP et al (1995) Climatic fluctuations, current variability and marine species distribution: a case study in the Ligurian Sea (north-west Mediterranean). Oceanol Acta 18:139-149

Babic K (1910) Prilog fauni Jadranskoga mora. Rad jugosl Akad Znan Umjetn 183:207-232

Babnik P (1948) Hidromeduze iz srednjega in junega Jadrana v letih 1939 in 1940. Hydromedusae from the middle and South Adriatic 1939 and 1940. Acta Adriat 3:275-340

Bavestrello G, Puce S, Cerrano C et al (2006) The problem of seasonality of benthic hydroids in temperate waters. Chem Ecol 22:197-205

Benović A, Lučić D (1996) Comparison of hydromedusae findings in the northern and southern Adriatic Sea. In: Piraino S, Boero F, Bouillon $\mathrm{J}$ et al (eds) Advances in Hydrozoan Biology. Sci Mar 60:129-135

Bevilacqua S, Fraschetti S, Terlizzi A et al (2009) The use of taxonomic distinctness indices in assessing patterns of biodiversity in modular organisms. Mar Ecol 30:151-163

Bianchi CN (2007) Biodiversity issues for the forthcoming tropical Mediterranean Sea. Hydrobiologia 580:7-21

Bianchi CN, Morri C (1993) Range extension of warm-water species in the northern Mediterranean: evidence for climatic fluctuations? Porcup Newsl 5:156-159

Bianchi CN, Morri C (2000) Marine biodiversity of the Mediterranean Sea: situation, problems and prospects for future research. Mar Pollut Bull 40:367-376

Bigelow HB (1909) Reports on the scientific results of the expedition to the eastern tropical Pacific, in charge of Alexander Agassiz, by the U.S. Fish Commission steamer "Albatross" from October, 1904, to March, 1905. XVI. Medusae. Mem Mus Comp Zool Harv 37:1-243

Bigelow HB (1912) Preliminary account of one new genus and three new species of medusae from the Philippines. Scientific results of the Philippine cruise of the fisheries steamer "Albatross", 1907-1910. No. 22. Proc US Natl Mus 43(1931):253-260

Billard A (1931) Hydroïdes des côtes de Syrie (Mission Gruvel). In: Gruvel A (ed) Les états de Syrie. Richesse marines et fluviales. Exploitation actuelle Avenir. Bibltque Faune Colon. Françaises 3:389-395

Bisby FA, Roskov YR, Orrell TM et al (eds) (2009) Species 2000 \& ITIS Catalogue of Life: 2009 annual checklist. CD-ROM. Species 2000, Reading, UK

Boero F (1994) Fluctuations and variations in coastal marine environments. PSZNI: Mar Ecol 15:3-25

Boero F (1996) Episodic events: their relevance in ecology and evolution. PSZNI: Mar Ecol 17:237-250

Boero F (2007) The history of the Hydrozoan Society, 1983-2007. Invertebr Zool 4:209-215 
Boero F (2014) The future of the Mediterranean Sea ecosystem: towards a different tomorrow. Rend Fis Acc Lincei. doi:10.1007/s12210-014-0340-y

Boero F, Bonsdorff E (2007) A conceptual framework for marine biodiversity and ecosystem functioning. Mar Ecol Evol Perspect 28(Suppl 1):134-145

Boero F, Gravili C (2013) The bio-ecology of marine extinctions, with a lesson from the Hydrozoa. In: Briand F (ed) Marine extinctions-patterns and processes_-Valencia (Spain) 10-13 Oct 2012. CIESM Workshop Monographs, 45. CIESM Publisher, Monaco, pp 75-79

Boero F, Féral JP, Azzurro E et al (2008) Climate warming and related changes in Mediterranean marine biota. CIESM Workshop Monogr 35:5-21

Boero F, Carlton J, Briand F et al (2013) Marine extinctions. Patterns and Processes. CIESM Workshop Monogr 45:5-19

Bonsdorff E, Blomqvist EM, Mattila J et al (1997) Coastal eutrophication-causes, consequences and perspectives in the archipelago areas of the northern Baltic Sea. Estuar Coast Shelf Sci 44:63-72

Bouillon J (1965) Diagnose préliminaire de trois hydroïdes de Roscoff. In: Teissier G (ed) Inventaire de la faune marine de Roscoff. Cnidaires-Cténaires. Trav Stn biol Roscoff 16:54

Bouillon J, Massin C, Kresevic R (1995) Hydroidomedusae de l'Institut royal des Sciences naturelles de Belgique. In: Van Ghoethem J (ed) Inst R Sci Nat Belg 78:1-106

Bouillon J, Medel MD, Pagès F et al (2004) Fauna of the Mediterranean hydrozoa. Sci Mar 68:1-449

Bouillon J, Gravili C, Pagès F et al (2006) An introduction to hydrozoa. Mém Mus Natl Hist Nat 194:1-598

Brinckmann A (1962) The life cycle of Merga galleri sp. n. (Anthomedusae, Pandeidae). Pubbl Staz zool Napoli 33:1-9

Brinckmann A (1964) Observations on the biology and development of Staurocladia portmanni sp. n. (Anthomedusae, Eleutheridae). Can J Zool 42:693-706

Brinckmann-Voss A (1966) The morphology and development of Acaulis ilonae sp. nov. (order Anthomedusae-Athecatae, Fam. Acaulidae). Can J Zool 44:291-301

Brinckmann-Voss A (1967) The hydroid of Vannuccia forbesii (Anthomedusae, Tubulariidae). Breviora 263:1-10

Brinckmann-Voss A (1970) Anthomedusae/Athecata (Hydrozoa, Cnidaria) of the Mediterranean, Part I. Capitata. Fauna e Flora Golfo di Napoli 39. Edizione della Stazione Zoologica di Napoli, Officine Grafiche Napoletane Francesco Giannini \& Figli, pp 1-96

Brinckmann-Voss A (1987) Seasonal distribution of hydromedusae (Cnidaria, Hydrozoa) from the Gulf of Naples and vicinity, with observations on sexual and asexual reproduction in some species. In: Bouillon J, Boero F, Cicogna F et al (eds) Modern trends in the systematics, ecology, and evolution of hydroids and hydromedusae. Clarendon Press, Oxford, pp 133-141

Broch H (1912) Hydroiduntersuchungen III. Vergleichende Studien an Adriatischen Hydroiden. Kgl Norske Vidensk Selsk Skr 1911 1:1-65

Broch H (1933) Zur Kenntis der Adriatischen Hydroidenfauna von Split. Arten und Variationen. Skr Norske Vidensk-Akad Oslo, Mat-Naturv Kl 1933 4:1-115

Butchart SHM, Stattersfield AJ, Baillie J et al (2005) Using Red List Indices to measure progress towards the 2010 target and beyond. Philos Trans R Soc Lond 360:255-268

Carlton JT, Geller JB, Reaka-Kudla ML et al (1999) Historical extinctions in the sea. Annu Rev Ecol Syst 30:515-538

Carus JV (1884) Prodromus faunae mediterraneae sive descriptiones animalium Mare Mediterranei incolarum quam comparata silva rerum quatenus innotuit adiectis locis et nominibus vulgaribus eorumque auctoribus in commodum zoologorum, pars I. Stuttgart E Schweizerbart'sche Verlagshandlung pp $1-524$

Casanova J-P (1980) Campagnes du "Meteor" dans l'Atlantique N-E. Siphonophores, Méduses et Thécosomes. Distribution verticale et comparaisons faunistiques avec la Méditerranée. "Meteor" ForschErbgeb (D) 32:15-32

Caziot E (1921) Espèces rares de la faune marine de la rade de Villefranche-sur-Mer (A.M.). Bull Soc Zool Fr 46:114-116

Chapin FS III, Zavaleta ES, Eviner VT et al (2000) Consequences of changing biodiversity. Nature 405:234-242

Çinar ME, Yokes MB, Açik S et al (2014) Check-list of Cnidaria and Ctenophora from the coasts of Turkey. Turk J Zool 38:1405-1468

Clarke KR, Warwick RM (1998) A taxonomic distinctness index and its statistical properties. J Appl Ecol 35:523-531

Clarke KR, Warwick RM (1999) The taxonomic distinctness measure of biodiversity: weighting of step lengths between hierarchical levels. Mar Ecol Prog Ser 184:21-29 
Clarke KR, Warwick RM (2001) A further biodiversity index applicable to species lists: variation in taxonomic distinctness. Mar Ecol Prog Ser 216:265-278

Claudet J, Fraschetti S (2010) Human-driven impacts on marine habitats: a regional meta-analysis in the Mediterranean Sea. Biol Conserv 143:2195-2206

Clausen C (1971) Interstitial Cnidaria: present status of their systematics and ecology. In: Hulings NC (ed) Proceedings of the first international conference on Meiofauna. Smithson Contrib Zool 76:1-8

Coll M, Piroddi C, Steenbeek J et al (2010) The biodiversity of the Mediterranean Sea: estimates, patterns, and threats. PLoS One 5:e11842. doi:10.1371/journal.pone.0011842

Cornelius PFS (1978) The genus names Calicella Hincks and Calycella Hincks (Coelenterata: Hydrozoa). Bull Br Mus Nat Hist Zool 33:233-234

Cornelius PFS (1979) A revision of the species of Sertulariidae (Coelenterata: Hydroida) recorded from Britain and nearby seas. Bull Br Mus Nat Hist Zool 34:243-321

Cornelius PFS (1982) Hydroids and medusae of the family Campanulariidae recorded from the eastern North Atlantic, with a world synopsis of genera. Bull Br Mus Nat Hist Zool 42:37-148

Cornelius PFS (1995) North-west European Thecate Hydroids and their Medusae (Cnidaria, Leptolida, Leptothecatae). In: Barnes RSK, Crothers JH (eds) Synopses of the British Fauna (New Series). The Linn Soc London Est Coas Sci Ass-Field Studies Council 2:1-386

Costello MJ, Wilson SP (2011) Predicting the number of known and unknown species in European seas using rates of description. Glob Ecol Biogeogr 20:319-330

Costello MJ, Emblow C, White R (eds) (2001) European register of marine species. A check-list of marine species in Europe and a bibliography of guides to their identification. Patrim Nat 50:1-463

Costello MJ, Bouchet P, Boxshall G et al (2013a) Global coordination and standardisation in marine biodiversity through the World Register of Marine Species (WoRMS) and related databases. PLoS One 8:e51629

Costello MJ, May RM, Stork NE (2013b) Can we name Earth's species before they go extinct? Science 339:413-416

Dayton PK, Thrush SF, Agardy MT et al (1995) Environmental effects of marine fishing. Aquat Conserv 5:205-232

De Filippi F (1866) Sopra due Idrozoi del Mediterraneo. Mem Accad Sci Torino, Scienze fisiche e matematiche, Serie 2(23):375-385

De Heer M, Kapos V, Ten Brinck BJE (2005) Biodiversity trends in Europe: development and testing of a species trend indicator for evaluating progress towards the 2010 target. Philos Trans R Soc Lond 360:297-308

De Vito D, Boero F, Di Camillo CG et al (2008) Redescription of the zooxanthellate Eudendrium moulouyensis (Eudendriidae: Hydrozoa) from the Mediterranean Sea. J Mar Biol Assoc UK 88:1655-1662

Du Plessis G (1881) Catalogue provisoire des hydroides médusipares (hydroméduses vraies) observés durant l'hiver 1879/80 à la Station zoologique de Naples. Mitt Zool Stn Neapel 2:143-149

Du Plessis G (1888) Faune des hydraires littoraux gymnoblastes observés à Villefranche sur Mer. Rec Zool Suisse 4:525-544

Dulvy NK, Sadovy Y, Reynolds JD (2003) Extinction vulnerability in marine populations. Fish Fish $4: 25-64$

Ebbecke U (1957) Reflexuntersuchungen an Coelenteraten. Pubbl Staz Zool Napoli 30:149-161

Eschscholtz F (1829) System der Acalephen. Eine ausführliche Beschreibung aller medusenartigen Strahltiere. Bei Ferdinand Dümmler, Berlin, p 190

Esper EJC (1788-1830) Die Pflanzenthiere. In: Abbildungen nach der Natur mit Farben erleuchtet 13. Raspischen Buchhandlung, Nürnberg, pp 1-162

Fontaine B, Bouchet P, Van Achterberg K et al (2007) The European union's 2010 target: putting rare species in focus. Biol Conserv 139:167-185

Galea HR (2007) Hydrozoa, La Ciotat and nearby areas, Mediterranean coast of France. Check List 3:193-199

Galil BS (1993) Lessepsian migration: new findings on the foremost anthropogenic change in the Levant basin fauna. In: Della Croce NFR (ed) Symposium Mediterranean Seas 2000. University of Genova, Istituto di Scienze Ambientali Marine, Santa Margherita Ligure, pp 307-323

Gegenbaur C (1857) Versuch eines Systemes der Medusen mit Beschreibung neuer oder wenig gekannter Formen; zugleich ein Beitrag zur Kenntniss der Fauna des Mittelmeeres. Z Wiss Zool 8:202-273

Gili JM (1982) Fauna de cnidaris de les illes Medes. Treballs Inst Catl Hist Nat 10:1-175

Gili JM, Castelló C (1985) Hidropólipos de la costa norte del Cabo de Creus (N.E. Cataluña). Hydroids of the north coast of Cape of Creus (Northeast Spain). Misc Zool Barc 9:7-24 
Gili JM, Garcia A, Colomer PL (1984) Els Cnidaris bentonics de les illes Medes. In: Ros J, Olivella I, Gili JM (eds) Els sistemes naturals de les illes Medes 73. Arxius de la Secciò de Ciènces, no 73 I.E.C., Barcelona, pp 407-427

Golani D (1998) Impact of Red Sea fish migrants through the Suez Canal on the aquatic environment of the eastern Mediterranean. Bull Yale Univ Sch For Environ Stud 103:375-387

Goy J (1971) Sur la répartition bathymétrique des hydroméduses en mer de Ligurie. Rapp P-v Réun Commn Int Explor Scient Mer Méditerr 20:397-400

Goy J (1973) Les Hydroméduses de la mer Ligure. Bull Mus Natl Hist Nat Paris 3, (83), Zool 62:965-1008

Graeffe E (1884) Uebersicht der Seethierfauna des Golfes von Triest, nebst Notizen über Vorkommen, Lebensweise, Erscheinungs- und Fortpfanzungszeit der einzelnen Arten. IlI Coelenteraten. Arb Zool Inst Univ Wien 5:333-362

Gravili C, Bouillon J, D'Elia A et al (2007) The life cycle of Gastroblasta raffaelei (Cnidaria, Hydrozoa, Leptomedusae, Campanulariidae) and a review of the genus Gastroblasta. Ital J Zool 74:395-403

Gravili C, D’Ambrosio P, Di Camillo C et al (2008) Clytia hummelincki (Hydroidomedusae: Leptomedusae) in the Mediterranean Sea. J Mar Biol Assoc UK 88:1547-1553

Gravili C, Belmonte G, Cecere E et al (2010) Nonindigenous species along the Apulian coast, Italy. Chem Ecol 26(Supplement):121-142

Gravili C, Di Camillo CG, Piraino S et al (2013) Hydrozoan species richness in the Mediterranean Sea: past and present. Mar Ecol Evol Perspect 34(Suppl 1):41-62

Gray JS (1989) Effects of environmental stress on species rich assemblages. Biol J Linn Soc 37:19-32

Greeff R (1869) Protohydra Leuckarti. Eine marine Stammform der Coelenteraten. Z wiss Zool 20:37-54

Grobben K (1915) Adriatic medusae collected by S.M.S. 'Najade'. Anz Akad Wiss Wien 52:2-5

Hadzi J (1914) Poredbena hidroidska istraivanja. III. Haleciella microtheca g. n., sp.n.; Georginella diaphana g. n., sp. n.; Halanthus adriaticus g. n., sp. n.; Campanopsis clausa (Hadzi) i o porodici Campanopsida uopce. Rad jugosl Akad Znan Umjetn, Mat Prir Razr 202:191-241

Hadzi J (1916) Rezultati biolokih istraivanja Jadranskoga mora. Hidroidi I. Ergebnisse biologischer Erforschungen des adriatischen Meeres. Hydroiden I. Camella vilae-velebiti g. n., sp. n. Croatella g. n. Prirod Istra hrv slav, mat-prirod Razreda (Bull Trav Cl Sci Mat Nat) 7:23-81

Haeckel E (1864) Beschreibung neuer Craspedoter Medusen aus dem Golfe von Nizza. Jena Z Med Naturwiss $1: 326-342$

Haeckel E (1879) Das System der Medusen. Erster Teil einer Monographie der Medusen. Denkschr Med Naturwiss Ges Jena 1:1-360

Hammond PM (1994) Practical approaches to the estimation of the extent of biodiversity in speciose groups. Philos Trans R Soc Lond 345:119-136

Harmelin J-G, d'Hont J-L (1993) Transfers of bryozoan species between the Atlantic Ocean and the Mediterranean Sea via the Strait of Gibraltar. Oceanol Acta 16:63-72

Hartlaub C (1889) Ueber die Claparède'sche “Eleutheria”. Zool Anz 12:665-671

Hartlaub C (1894) Die Coelenteraten Helgolands. Vorläufiger Bericht. Wiss Meeresunters N Ser 1:161-206

Hartlaub C (1909) Über einige von Ch. Gravier in Djibuti gesammelte Medusen. Zool Jb Syst 27:447-476

Heller C (1868) Die zoophyten und Echinodermen des Adriatischen Meeres. Verh k Zool-Bot Ges Wien 18:1-88

Hilchey J (2003) The importance of protecting marine biodiversity. http://www.marinebiodiversity.ca/en/ pdfs/Jeff_Hilcheys_Essay.pdf. Accessed 30 June 2014

Hughes L (2000) Biological consequences of global warming: is the signal already. Tree 15:56-61

Huvé P (1954) Hydranthea et Campalecium, genres méditerranéens aberrants d'Hydroides de la famille des Haleciides. Recl Trav Stn Mar Endoume 13:173-192

Jablonski D (1986) Causes and consequences of mass extinctions: a comparative approach. In: Elliott DK (ed) Dynamics of extinction. Wiley, New York, pp 183-229

Jackson JBC (2008) Ecological extinction and evolution in the brave new ocean. Proc Natl Acad Sci USA 105:11458-11465

Katsanevakis S, Gatto F, Zenetos A, Cardoso AC (2013) How many marine aliens in Europe? Manag Biol Invasion 4:37-42

Keferstein W, Ehlers E (1861) Zoologische Beiträge gesammelt in winter 1859-1860 in Neapel und Messina. W Engelman, Leipzig, p 112

Kölliker A (1853) Bericht über einige im Herbste 1852 in Messina angestellte vergleichend-anatomische Untersuchungen, in Gegenbaur, Kölliker \& Muller, 1853. Z Wiss Zool 4:298-370

Kramp PL (1924) Medusae. In: Report on the Danish oceanographical expeditions, 1908-1910, vol 2. Biol H1: $1-67$

Kramp PL (1947) Hydroids collected by the "Skagerak" expedition in the eastern Atlantic 1946. Göteb Kungl Vetensk-och Vitterh-Samh Hand 5:1-16 
Kramp PL (1953) Hydromedusae. Sci Rep Gr Barrier Reef Exped 6:259-322

Kramp PL (1955) The medusae of the tropical West Coast of Africa. Atlantide Rep 3:239-324

Kramp PL (1957a) Some Mediterranean Hydromedusae collected by A.K. Totton in 1954 and 1956. Vidensk Meddr dansk naturh Foren 119:115-128

Kramp PL (1957b) Hydromedusae from the discovery collections. Discov Rep 29:1-128

Kramp PL (1961) Synopsis of the medusae of the world. J Mar Biol Assoc UK 40:1-469

Lejeusne C, Chevaldonné P, Pergent-Martini C et al (2010) Climate change effects on a miniature ocean: the highly diverse, highly impacted Mediterranean Sea. Trends Ecol Evol 4:250-260

Linnaeus C (1758) Systema naturae per regna tria naturae, secundum classes, ordines, genera, species cum characteribus, differentiis, synonymis, locis. Edition decima, reformata. Laurentii Salvii, Holmiae, 823

Linnaeus C (1767) Systema naturae. Twelfth edition. Holmiae (Stockholm), L Salvii, vol 1, part 2, pp 533-1328 + 36 pp of unpaginated indexes and appendix

Lo Bianco S (1903) Le pesche abissali eseguite da F.A. Krupp col yacht Puritan nelle adiacenze di Capri ed in altre località del Mediterraneo. Mitt Zool Stn Neapel 16:109-279

Lo Bianco S (1909) Notizie biologiche riguardanti specialmente il periodo di maturità sessuale degli animali del Golfo di Napoli, Hydromedusae. Mitt Zool Stn Neapel 19:538-545

Maas O (1893) Die Craspedoten Medusen der Plankton Expedition. Ergebnisse d. In: dem Atlantischen Ocean von Mitte Juli bis Anfang November 1889 ausgeführten Plankton-Expedition der Humboldt Stiftung 2(Kc):1-107

Marinopulos J (1992) Taxonomy and phylogeny of the Mediterranean Eudendrium (Hydrozoa, Hydroida). Bull Inst Océanogr Monaco Spec 9:53-66

Marktanner-Turneretscher G (1890) Die Hydroiden des k. k. naturhistorischen Hofmuseums. Ann Naturhist Hofmuseums 5:195-286

Marshall CR (1990) Confidence intervals on stratigraphic ranges. Paleobiology 16:1-10

Mastrototaro F, D'Onghia G, Corriero G et al (2010) Biodiversity of the white coral bank off Cape Santa Maria di Leuca (Mediterranean Sea): an update. Deep-Sea Res II 57:412-430

May RM (1994) Past efforts and future prospect towards understanding how many species there are. In: Solbrig OT, van Emden HM, van Oordt PGW (eds) Biodiversity and global change. CAB International, Paris, pp 71-84

Mayer AG (1894) An account of some medusae obtained in the Bahamas, in Cruise of the Steam Yacht "Wild-Duck" in the Bahamas, January to April 1893, in charge of Alexander Agassiz. Bull Mus Comp Zoöl Harv 25:235-242

Mayer AG (1900a) Descriptions of new and little-known medusae from the western Atlantic. Bull Mus Comp Zoöl Harv 37:1-9

Mayer AG (1900b) Some medusae from the Tortugas, Florida. Bull Mus Comp Zoöl Harv 37:13-82

Mayer AG (1910c) Medusae of the world. Hydromedusae, Vols. I \& II. Scyphomedusae, Vol. 3, Carnegie Institution, Washington, p 735

Mendelson JR III, Lips KR, Gagliardo RW et al (2006) Confronting amphibian declines and extinctions. Science 313:48

Metschnikoff E (1886a) Medusologische Mittheilungen. Arb Zool Inst Univ Wien 6:237-266

Metschnikoff E (1886b) Embryologische Studien an Medusen. Ein Beitrag zur Genealogie der PrimitivOrgane. Verlag v Alfred Hölder, kk Hof-u Universitäts-Buchhändler in Wien, pp 1-159

Metschnikoff E, Metschnikoff L (1871) Ueber die Entwickelung einiger Coelenteraten. Bull Acad Imp Sci St Pétersb 15:95-100

Monniot F (1962) Recherches sur les graviers à Amphioxus de la région de Banyuls-sur-Mer. Vie Milieu $13: 231-322$

Mora C, Tittensor DP, Adl S et al (2011) How many species are there on Earth and in the ocean? PLoS Biol 9:e1001127. doi:10.1371/journal.pbio.1001127

Morri C, Puce S, Bianchi CN et al (2009) Hydroids (Cnidaria: Hydrozoa) from the Levant Sea (mainly Lebanon), with emphasis on alien species. J Mar Biol Assoc UK 89:49-62

Motz-Kossowska S (1905) Contribution à la connaissance des hydraires de la Méditerranée occidentale. I. Hydraires gymnoblastiques. Arch Zool Exp Gén 4e Série 3:39-98

Myers N, Mittermeier RA, Mittermeier CG et al (2000) Biodiversity hotspots for conservation priorities. Nature 403:853-858

Neppi V (1915) Vorläufige Mitteilungen über die während der Terminfahrt der Najade im Adriatischen Meer gesammelten Hydromedusen. Anz Akad Wiss Wien 52:1-5

Neppi V (1922) Meduse adriatiche (Risultato dell'esame del materiale raccolto durante le crociere adriatiche delle nave Najade negli anni 1911-14). Mem R Com Talassogr Ital 101:1-38

Neppi V, Stiasny G (1911) Die Hydromedusen des Golfes von Triest. Zool Anz 38:395-399 
Neppi V, Stiasny G (1913) Die Hydromedusen des Golfes von Triest. Arb Zool Inst Univ Wien Zool Stn Triest 20:23-92

Nyholm KG (1951) A contribution to the study of the sexual phase of Protohydra leuckarti. Ark Zool 2:529-530

Pallas PS (1766) Elenchus zoophytorum sistens generum adumbrationes generaliores et specierum cognitarum succinctas descriptiones, cum selectis auctorum synomymis. Hagae Comitum i-xxviii: 451

Pavesi P (1878) I Celenterati. Enciclopedia medica italiana del dott. Francesco Vallardi, Milano

Pearson TH, Rosemberg R (1978) Macrobenthic succession in relation to organic enrichment and pollution of the marine environment. Oceanogr Mar Biol Annu Rev 16:229-311

Pell M (1918) Hydromedusae of Hungarian Adriatic ('Najade') expeditions 1913, 1914. Allat Köslem $17: 22-32$

Pell M (1938) The hydromedusae of the Adriatic, collected by the "Najade". Mat Termész Ert 57:919-930

Péron F, Lesueur CA (1810) Tableau des caractères génériques et spécifiques de toutes les espèces de méduses connues jusqu'à ce jour. Ann Mus Hist Nat Paris 14:325-366

Picard J (1951a) Les hydraires des formations coralligènes des côtes françaises de la Méditerranée. Vie Milieu 2:255-261

Picard J (1951b) Note sur les hydraires littoraux de Banyuls-sur-Mer. Vie Milieu 2:338-349

Picard J (1958a) Origines et affinités de la faune d'hydropolypes (Gymnoblastes et Calyptoblastes) et d'hydroméduses (Anthoméduses et Leptoméduses) de la Méditerranée. Rapp P-v Réun Commn Int Explor Scient Mer Méditerr 14:187-199

Picard J (1958b) Tregoubovia n. gen. atentaculata n. sp. Nouvelle Anthoméduse, dépourvue de tentacules récolté dans le plancton profond de Villefranche-sur-mer. Rapp P-v Réun Commn Int Explor Scient Mer Méditerr 14:185-186

Pieper FW (1884) Ergänzungen zu "Heller's Zoophyten etc. des adriatischen Meeres". Zool Anz 7:148-152, 164-169, 185-188, 216-221

Piraino S, De Vito D, Brodbeck E et al (2013) Destructive standard squares or low-impact visually driven collection? A comparison of methods for quantitative samplings of benthic hydrozoans. Ital J Zool 80:424-436

Por FD (1999) The great levantine landbridge and the resilient fragment of Tethys. Contributions to the Zoogeography and Ecology of the Eastern Mediterranean Region. 7th International congress of the zoogeography and ecology of Greece and adjacent regions 1:27-36

Puce S, Bavestrello G, Di Camillo CG et al (2009) Long-term changes in hydroid (Cnidaria, Hydrozoa) assemblages: effect of Mediterranean warming? Mar Ecol Evol Perspect 30:313-326

Ranson G (1925) Quelques observations sur le plancton et liste des méduses recueillis par La Tanche pendant sa croissière de 1924. Bull Mus Natl Hist Nat Paris 31:379-382

Ranson G (1936) Méduses provenant des Campagnes du Prince Albert I de Monaco. Rés Camp Scient Prince Albert I Monaco 92:1-245

Régnier C, Fontaine B, Bouchet P (2009) Not knowing, not recording, not listing: numerous unnoticed mollusk exrinctions. Conserv Biol 23:1214-1221

Remane A (1927) Halammohydra, ein eigenartiges Hydrozoon der Nord- und Ostsee. Z Morph Ökol Tiere 7:643-677

Riedl R (1959) Die Hydroiden des Golfes von Neapel und ihr Anteil an der Fauna unterseeischen Höhlen. In: Ergebnisse der österreichischen Tyrrhenia-Expedition 1952, Teil xvi. Pubbl Staz Zool Napoli 30:591-755

Roberts CM, Hawkins JP (1999) Extinction risk in the sea. Trends Ecol Evol 14:241-246

Rossi L (1950) Celenterati del Golfo di Rapallo (Riviera Ligure). Boll Mus Zool Univ Torino 2:193-235

Salvini-Plawen LV (1966) Zur Kenntnis der Cnidaria des nordadriatischen Mesopsammon. Veröff Inst Meeresforsch Bremerhav, Sonderbd 2:165-186

Sarà M (1985) Ecological factors and their biogeographic consequences in the Mediterranean ecosystem. In: Moraitous-Apostolopoulou M, Kiortsis V (eds) Mediterranean Marine Ecosystems. Plenum Press, New York, pp 1-17

Schmidt HE (1973) Biogeographical problems of the Red Sea area exemplified by hydroids. In: Zeitschel B (ed) The biology of the Indian Ocean (J. Jacobs et al, Ecological studies, analysis and synthesis 3). Springer, New York, pp 283-287

Schneider KC (1898) Hydropolypen von Rovigno, nebst Uebersicht uber das System der Hydropolypen in allgemeinen. Zool Jb Syst 10:472-555

Schuchert P (2001) Survey of the family Corynidae (Cnidaria, Hydrozoa). Rev Suisse Zool 108:739-878

Schuchert P (2005) Rediscovery of Coryne fucicola (de Filippi, 1866) (Cnidaria: Hydrozoa). Cah Biol Mar 46:305-310 
Schuchert P (2006) The European athecate hydroids and their medusae (Hydrozoa, Cnidaria): Capitata part 1. Rev Suisse Zool 113:325-410

Schuchert P (2007) The European athecate hydroids and their medusae (Hydrozoa, Cnidaria): Filifera part 2. Rev Suisse Zool 114:195-396

Schuchert P (2008a) The European athecate hydroids and their medusae (Hydrozoa, Cnidaria): Filifera part 3. Rev Suisse Zool 115:221-302

Schuchert P (2008b) The European athecate hydroids and their medusae (Hydrozoa, Cnidaria): Filifera part 4. Rev Suisse Zool 115:677-757

Schuchert P (2009) The European athecate hydroids and their medusae (Hydrozoa, Cnidaria): Filifera part 5. Rev Suisse Zool 116:441-507

Schuchert P (2010) The European athecate hydroids and their medusae (Hydrozoa, Cnidaria): Capitata part 2. Rev Suisse Zool 117:337-555

Schuchert P (2013) World Hydrozoa database. http://www.marinespecies.org/hydrozoa/aphia.php?p= taxdetails\&id=117831. Accessed 20 Sept 2013

Schulz E (1950) Psammohydra nanna, ein neues solitäres Hydrozoon in der westlichen Beltsee. (Studien an Hydrozoa, II). Kieler Meeresforsch 7:122-137

Schulze FE (1876) Tiarella singularis, ein neuer Hydroidpolyp. Z Wiss Zool 27:403-416

Spagnolini A (1871) Catalogo degli Acalefi discofori del Golfo di Napoli. Atti Soc Ital Sci Nat 14:141-223

Spagnolini A (1877) Catalogo sistematico degli Acalefi del Mediterraneo. Sifonofori e Meduse Craspedote. Atti Soc Ital Sci Nat 19:1-45

Sparnocchia S, Manzella GMR, La Violette PE (1994) The interannual and seasonal variability of the MAW and LIW core properties in the Western Mediterranean Sea. Coast Estuar Stud 46:177-194

Stechow E (1921) Neue genera und species von hydrozoen und anderen evertebraten. Arch Naturg $87: 248-265$

Stechow E (1923) Zur Kenntis der Hydroidenfauna des Mittelmeeres, Amerikas und anderer Gebiete. II. Teil. Zool Jb Syst 47:29-270

Strauss D, Sadler PM (1987) Confidence intervals for the ends of local taxon ranges. Technical Report 158. Department of Statistics, University of California; Riverside, California

Strauss D, Sadler PM (1989) Classical confidence intervals and Bayesian probability estimates for ends of local taxon ranges. Math Geol 21:411-427

Swedmark B (1956) Étude de la microfaune des sables marins de la région de Marseille. Arch Zool Exp Gén 2:70-95 (93, notes et revue)

Swedmark B, Teissier G (1958) Armorhydra janowiczi n. g., n. sp. Hydroméduse bentique. C R Hebd Séanc Acad Sci Paris 247:133-135

Templado J (2014) Future trends of Mediterranean biodiversity. In: Goffredo S, Dubinsky Z (eds) The Mediterranean Sea: its history and present challenges. Springer, Dordrecht, pp 479-498

Trégouboff G, Rose M (1957) Manuel de Planctonologie Méditerranéenne. C.N.R.S., Paris. Tome I, pp 1-587. Tome II. Planches: 62-93

Vanhöffen E (1902) Die Acraspeden Medusen der deutschen Tiefsee- Expedition 1898-1899. Die Craspedoten Medusen der deutschen Tiefsee Expedition 1898-1899, I. Trachymedusen. Wissenschaftliche Ergebnisse der Deutschen Tiefsee-Expedition auf dem Dampfer "Valdivia” 1898-1899, 3:1-52, 55-86

Vanhöffen E (1913) Die Craspedoten Medusen des "Vettor Pisani”. Zool Stuttg 26:1-34

Vannucci M (1966) Total net plankton volume and hydromedusae from fixed stations in the Gulf of Naples. In: Barnes $\mathrm{H}$ (ed) Some contemporary studies in marine sciences. Allen and Unwin, London, pp 675-697

Wright TS (1859) Observations on British zoophytes. Edinb New Phil J 10:105-114

Zenetos A, Gofas S, Morri C et al (2012) Alien species in the Mediterranean Sea by 2012. A contribution to the application of European Union's Marine Strategy Framework Directive (MSFD). Part 2. Introduction trends and pathways. Mediterr Mar Sci 13:328-352

Zoja R (1893) Intorno ad un nuovo idroide. Mitt Zool Stat Neapel 10:519-526

Zoja R (1896) Una nuova medusa (Octogonade mediterranea n. g. n. sp.). Boll Scient Milano 17:101-106 